\title{
Thecamoebians from recent lake sediments from the Šumava Mts, Czech Republic
}

\author{
MARKÉTA LORENCOVÁ
}

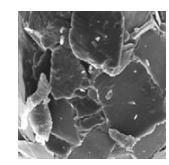

\begin{abstract}
Assemblages of thecamoebians (testate amoebae) were studied in forty-six surface samples of recent bottom sediments from five lakes in the Šmava Mts, Czech Republic. Altogether, twelve species of thecamoebians with anorganic wall were identified. The most abundant species, contained in $96 \%$ of samples, was Difflugia globulus. Other common species were Difflugia oblonga and Centropyxis orbicularis. Using cluster analysis it was possible to distinguish three main thecamoebian assemblages. The Difflugia globulus assemblage (66-100\% of D. globulus) dominates in Plešné Lake, characterized by a higher phytoplankton content. The Difflugia globulus diversified cluster (4-64\% of Difflugia globulus, 3-8 species in total) has the greatest species diversity and dominates in Laka Lake, characterized by the lowest phytoplankton biomass. The transitional Difflugia globulus and Pontigulasia compressa cluster (55-78\% of Difflugia globulus, $12-32 \%$ of Pontigulasia compressa) occurs in lakes with medium values of phytoplankton biomass (Černé, Čertovo, Prášilské lakes). All the species found should be adaptable to low $\mathrm{pH}(<6)$ because of the long term acidity of the investigated lakes. The species Difflugia globulus, Difflugia oblonga and Centropyxis orbicularis are characteristic for these lakes. The invariable morphology of Centropyxis orbicularis simplifies its identification and makes this species a good candidate as a palaeoenvironmental indicator. A comparison of recently evidenced taxa with the data from Černé Lake and Čertovo Lake published by Frič \& Vávra (1898) was also made. Six new species have been found in these lakes (Euglypha acanthopora, Centropyxis orbicularis, Centropyxis constricta, Difflugia viscidula, Nebela vitraea, Pontigulasia compressa). - Key words: testate amoebae, thecamoebians, actuoecology, statistical analysis, Šumava Mts.
\end{abstract}

LORENCOVÁ, M. 2009. Thecamoebians from recent lake sediments from the Šumava Mts, Czech Republic. Bulletin of Geosciences 84(2), 359-376 (13 figures, 5 tables). Czech Geological Survey, Prague. ISSN 1214-1119. Manuscript received March 19, 2008; accepted in revised form January 26, 2009; published online May 12, 2009; issued June 30, 2009 .

Markéta Lorencová, Charles University, Institute of Geology and Paleontology, Albertov 6, CZ-128 43 Praha 2, Czech Republic; mar.lor@seznam.cz

Thecamoebians (testate amoebae) are a large group of freshwater amoeboid protozoans with agglutinated or autogenous tests. They are present in a wide range of habitats soil, moss, peat, running or standing water and other moist localities. These organisms are a component of the freshwater benthos which inhabite various types of sediment (from mineral substrate with various clasts to substrate rich in sapropel). They can encyst and thus are able survive adverse conditions. Most of the species are cosmopolitan. Fossils of thecamoebians are abundant in Quaternary freshwater sediments (Medioli et al. 1990). Their capability for encystment, enabling them to withstand almost every unfavorable condition, keeps their evolution on a low level due to zero evolutionary pressure (Scott et al. 2001). An understanding of the ecology of modern thecamoebians enables palaeoecological reconstructions of freshwater environments (Scott et al. 2001). The use of thecamoebians as ecological and subsequently palaeoecological indicators has been the subject of many recent studies (e.g., Charman 2001, Medioli et al. 1990).

Studies of modern thecamoebian assemblages in recent sediments from lakes in the Šumava Mts, south Czech Republic, have been undertaken to assess their use as paleoenvironmental indicators in sediments. Thecamoebians from this area were the subjects of some earlier studies. The species from mosses were analyzed by Bartoš (1949, 1951) and Balík (1992), soil thecamoebians by Rosa (1958) and lacustrine thecamoebians by Frič \& Vávra (1898). Detailed variability of thecamoebian assemblages in aquatic environments were analyzed by Holcová \& Lorencová (2004a). Different assemblages from stream microhabitats were studied by Holcová (2007). This paper describes lacustrine assemblages from the five lakes of glacial origin in the Šumava Mts.

Many studies dealing with lacustrine fauna have been carried out in North America, especially in Canada (Scott 


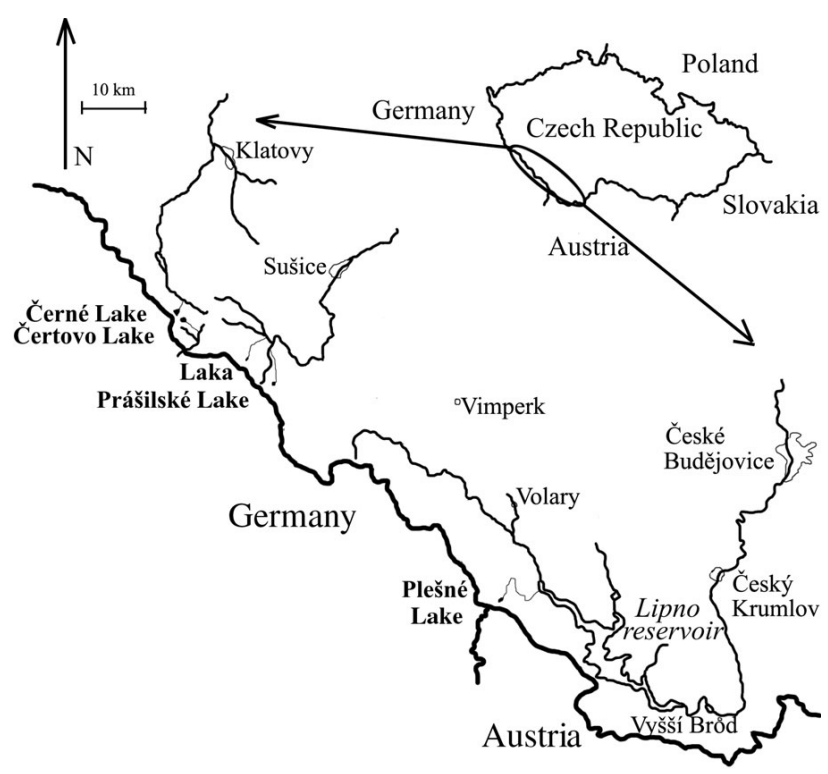

Figure 1. Schematic map showing the location of studied lakes.

\& Medioli 1983a, b; Patterson et al. 1985; Honig \& Scott 1987; McCarthy et al. 1995; Patterson et al. 1996; Burbidge \& Schröder-Adams 1998; Dallimore et al. 2000; Patterson \& Kumar 2000a). Some studies were also published from European lakes (Schönborn 1962; Štěpánek 1967; Golemansky 1970, 1973; Asioli \& Medioli 1992; Ellison 1995; Asioli et al. 1996). The assemblages in lakes from other parts of the world are less well known (Balík \& Song 2000, Dalby et al. 2000).

The purpose of this study was to relate thecamoebian species or characteristics to limnological parameters of lakes in the Šumava Mts. Such data can be effectively used as paleoenvironmental indicators in older sediments. It is for the first time that thecamoebian fauna from recent sediments from the Šumava Mts lakes were examined on such a complex scale. Moreover, this research is closely linked to investigation of thecamoebians in other freshwater environments in the area of the Sumava Mts (Holcová \& Lorencová 2004a, Holcová in press). The taxonomical concept utilised in this paper follows the typical approach used when analyzing thecamoebians in paleoecology, in contrast to the typical biological approach. This study uses the approach to thecamoebian taxonomy outlined in Medioli \& Scott (1983) and Scott et al. (2001) which is based on fossil rather than biological assemblages. The results could also be utilized as comparative data for arcellacean fauna and variations in its assemblages depending on current limnological conditions. Last but not least, this research could be a reminder that thecameobians maybe a possible freshwater equivalent to foraminifers, and bring to the forefront the necessity for detailed study of these organisms in the paleontological record as well as in recent sediment.

\section{The Šumava Mts and the studied lakes}

The Šumava Mts are a NW-SE elongated hilly range, located along the border of the Czech Republic with Germany and Austria, with the highest hills reaching altitudes above $1400 \mathrm{~m}$ a.s.l. The German name of this hilly range is Böhmerwald (Bavarian Forest), the Austrian part is called Mühlviertel. The whole unit represents the largest forest complex in Central Europe, with nature protected on both sides of the border.

From the geological point of view, the Šumava Mts represent the southern part of the Moldanubicum geological unit, belonging to the Bohemian Massif. Granites, gneisses and mica-shists of Proterozoic to Lower Palaeozoic age dominate in the area. All these silicate rocks have a low ability to buffer acid precipitation and the whole area became acidified as a result of a decrease in precipitation $\mathrm{pH}$ during the industrial period.

The present-day geomorphology of the area was significantly affected by block movements related to Alpine orogenies in the south-located Alps during the Tertiary. Erosion and other processes have created a rolling landscape with a large upland plateau, slightly arched tops, deep valleys and glacial cirques with glacial lakes, which were formed during the glacial periods of the Quaternary (Albrecht et al. 2003, Veselý 1994). There are five lakes of glacial origin on the Czech side of the border, all enclosed by end moraines, and all located at approximately the same altitude of 1000-1100 m a.s.1. - Plešné Lake, Černé Lake, Čertovo Lake, Prášilské Lake and Laka Lake (Fig. 1). The moraine ramparts damming the lakes were artificialy modified and heightened in most cases.

The climate in the Šumava Mts is temperate with relatively small annual fluctuations in temperature (January average temperature $-4.0^{\circ} \mathrm{C}$, July average temperature $13.1{ }^{\circ} \mathrm{C}$, measured at the Churáňov station at an elevation of $1118 \mathrm{~m}$ a.s.l.), and with relatively high annual precipitation of 800-1600 mm/year. The temperature and precipitation distribution is strongly dependent on altitude. The average yearly temperature ranges between $6^{\circ} \mathrm{C}$ at $750 \mathrm{~m}$ a.s.1., and $3{ }^{\circ} \mathrm{C}$ at about $1300 \mathrm{~m}$ a.s.l. (Albrecht et al. 2003). The water temperature of the lakes oscillates from approximately 0 to $20^{\circ} \mathrm{C}$, there is summer and winter stratification in all of the lakes except Laka Lake (Janský et al. 2003). The lakes are covered by ice for approximately 4 to 6 months of the year (Janský et al. 2003).

Studies of the lakes have been ongoing for more than 130 years. Significant changes in plankton composition and disappearance of fish resulting from lake water acidification were described (Frič \& Vávra 1898, Fott et al. 2001, Nedbalová 2001). Long-term monitoring of the changes in limnological and hydrobiological characteristics of the lakes and reasons for their acidification are given in Kopáček et al. (1998), Nedbalová et al. (2006), Veselý (1994, 
Markéta Lorencová • Thecamoebians from recent lake sediments from the Šumava Mts

Table 1. Geographical coordinates and main characteristic of the lakes, ${ }^{1)}$ own data (GPS), ${ }^{2)}$ Janský et al. 2005, ${ }^{3)}$ Veselý $1996,{ }^{4)}$ Vrba et al. 2002.

\begin{tabular}{|c|c|c|c|c|c|}
\hline Parameter / Lake & Plešné Lake & Prášilské Lake & Černé Lake & Čertovo Lake & Laka Lake \\
\hline N latitude ${ }^{1)}$ & $48^{\circ} 47^{\prime}$ & $49^{\circ} 05^{\prime}$ & $49^{\circ} 11^{\prime}$ & $49^{\circ} 10^{\prime}$ & $49^{\circ} 07^{\prime}$ \\
\hline E longitude ${ }^{1)}$ & $13^{\circ} 52^{\prime}$ & $13^{\circ} 24^{\prime}$ & $13^{\circ} 11^{\prime}$ & $13^{\circ} 12^{\prime}$ & $13^{\circ} 20^{\prime}$ \\
\hline altitude a.s.l. $[\mathrm{m}]^{2)}$ & 1087 & 1079 & 1007 & 1027 & 1084 \\
\hline lake area $[\mathrm{ha}]^{2)}$ & 7.6 & 4.2 & 18.8 & 10.7 & 2.6 \\
\hline $\max$. depth $[\mathrm{m}]^{2)}$ & 18.7 & 17.2 & 40.1 & 35.4 & 3.5 \\
\hline mean depth $[\mathrm{m}]^{2)}$ & 8 & 8.3 & 15.6 & 17.3 & 1.9 \\
\hline $\mathrm{pH}$ in $1999^{4)}$ & 5.17 & 5.08 & 4.78 & 4.5 & 5.81 \\
\hline volume $\left[\text { mil. } \mathrm{m}^{3}\right]^{2)}$ & 0.61 & 0.35 & 2.92 & 1.86 & 0.05 \\
\hline catchment area $[\mathrm{ha}]^{2)}$ & 67 & 65 & 124 & 89 & 102 \\
\hline residence time [year] ${ }^{3)}$ & 1.3 & 0.8 & 3.5 & 3.2 & 0.05 \\
\hline biomass of phytoplankton $[\mu \mathrm{g} / \mathrm{l} \mathrm{C}]^{4)}$ & 487 & 118 & 170 & 167 & 49 \\
\hline geology of watersheds ${ }^{3)}$ & granite & mica-shists, quartzite & mica-shists & mica-shists, quartzite & granite, mica-shists \\
\hline
\end{tabular}

1996), Vrba et al. (2003) and Vrba et al. (2004). Factors affecting the chemistry of glacial lakes are examined in Kopáček et al. (2001). Majer et al. (2001) suggested a model for future evolution of lake chemistry for Plešné Lake. The recent status in geographic research is summarized in Janský et al. (2003, 2005). Basic descriptive parameters of the lakes are contained in Table 1.

The first observation of lacustrine thecamoebians in Šumava Mts was described by Frič \& Vávra (1898) in Černé Lake and Čertovo Lake. Their research was concentrated on various aspects (botanical, zoological, hydrological, geographical, bathymetric, limnological), and was not specialized on thecamoebians. Moreover, the taxonomic view and species determination has undergone many changes since that time. Nevertheless, a comparison of these historical data with recent results can be quite useful (see Results chapter).

The studied lakes of glacial origin (Plešné Lake - PL, Černé Lake - CN, Čertovo Lake - CT, Prášilské Lake - PR and Laka Lake - LA, see Fig. 1) in the Czech part of Šumava Mts, with lake areas ranging from 2.6 ha to 18.8 ha, represent unique ecosystems, with rare species and specific biological communities. The watersheds of the lakes are relatively small, with steep slopes covered predominantly by mature spruce stands. The watersheds of the studied lakes were affected by various human activities (e.g., ore prospecting and mining, forest management including logging, glass production, pasturing, dam and sluice construction, fishing and fish introduction, etc.). These activities have occurred here since the middle of the $17^{\text {th }}$ century (Veselý 1994, Vrba et al. 1996), but occurence was reduced after 1960 when the Šumava Mts became a protected area. Nevertheless, at the same time, the Sumava Mts were affected by acid rains resulting from atmospheric transport of anthropogenic sulphur and nitrogen oxides. The scale and rate of these changes in the lakes resulting from this atmospheric pollution are unique in the world.
The processes in the Šumava Mts catchments and lakes differ from those causing acidification in the Scandinavian and Canadian lakes especially in intensity of the acidification, and in high concentration of nitrates (Veselý \& Majer 1992, Veselý 2000b). The watersheds are dominated by crystalline, calcium-poor rocks with limited ability to neutralize the acid precipitation, and by naturally forested or re-forested catchment areas. The anthropogenic atmospheric acidification presumably began as early as the 1950 's but certainly by the 1960's and lake acidification peaked in the 1970's. A reversal in the acidification trend began in the mid-1980's (Vrba et al. 2000). During the 1990s, the deposition of sulphur and nitrogen compounds decreased due to a drop in their emissions in Central Europe (Kopáček et al. 1998, Veselý \& Majer 1992). As a result of these complex processes, all studied lakes are acidified to a different degree, even some signs of recovery from acidity have been observed during the last decade (Nedbalová et al. 2006). Generally PL, CN and CT are strongly acidified, PR is moderately acidified, and LA is only slightly acidified (data from the year of 2000, Vrba et al. 2000). Nedbalová et al. (2006) indicated that PR and LA were moderately acidified in 2003. A statistical comparison of seasonal data showed a significant increase in $\mathrm{pH}$ and a significant drop in total reactive aluminium in the period 1997-2003 (Vrba et al. 2004).

At the bottom of these lakes, an oxygen deficit is generally observed (Veselý et al. 2004), except for CN and LA. The lakes are stratified and their water is mixed twice a year (dimictic lakes), except for the shallow LA (Vrba et al. 2002). The sedimentation rate can vary greatly at different depths in the lakes. Sediment core studies show that the sedimentation rates are mostly between 1 and $2 \mathrm{~mm} / \mathrm{yr}$ in the deep central parts of CN and CT (Veselý 1994). Hejzlar et al. (1998) estimated a sedimentation rate of about $1 \mathrm{~mm} / \mathrm{yr}$ in PL. These sedimentation rates can be valid mostly for the central sections of the lake bottoms. 


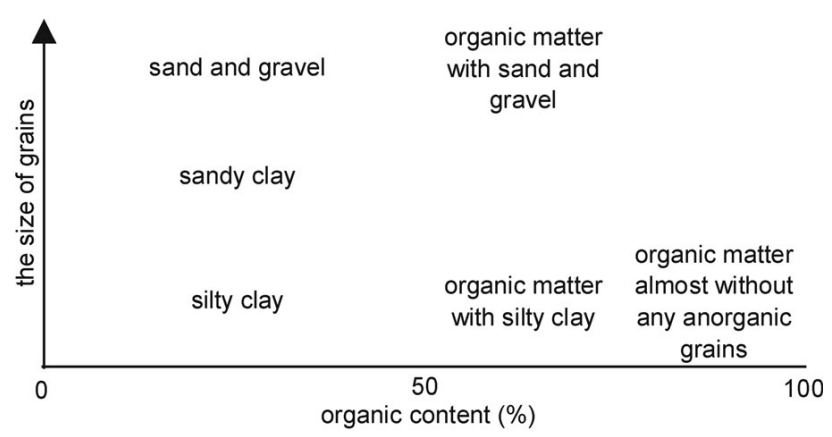

Figure 2. Types of sediment analyzed.

The sections along the lake shores show either lower (where wave action washes the sediment to a deeper section) or higher (near the small inflows) sedimention rates. All the studied lakes have catchments with a small area and only small inflow streams, which transport relatively small quantities of coarse clastic material. According to their trophic status, the lakes can be divided into two groups: oligotrophic $(\mathrm{CN}, \mathrm{CT})$ and mesotrophic (PL, PR, LA).

\section{Material and methods}

Forty-six samples were collected in June 2002 from the surface layer of the sediments from the bottom of the selected lakes. The localities were chosen in order to sample as many types of environments, substrates and water depths as possible. Substrates included silty clay, sandy clay, sand and gravel and organic matter-rich sediment, containing more than $50 \%$ organic matter of various origins (Fig. 2). Sampling was carried out from a small boat by hand or using a simple sampling device in deeper parts. The geographical location of each sample site was measured using GPS (Global Positioning System) and recorded on detailed maps. Photos of the locality, including the immediate surroundings were also taken. Water depth, distance from the actual shore line, characteristics of the bottom and the sediment present, and types of water plant vegetation in the vicinity were recorded (Table 2 ). An approximately $1 \mathrm{~cm}$ thick layer of the sediment/water interface from an area of $c a 25 \mathrm{~cm}^{2}$ was sampled. At most sites sampled, this thickness of the sediment layer should correspond to ten years of sedimentation (i.e. 1992-2002, cf. Veselý 1994), or less. In some cases where coarse clastic sediments were sampled, the sample could integrate longer periods of time, since the fine-grained portion of the sediment could have accumulated in the interstitial spaces of the gravel or sand.

The number of samples from the lakes was seleceted depending on the lake area, with the lowest number being 6 samples from the smallest LA, and highest number being
11 samples from both CN and CT. In three cases (PL34/02, PL35/02, CT57/02) the same sample area was sampled twice or three times at distances of $5-10 \mathrm{~cm}$ between replicated or triplicated samples, to detect possible local variability in the assemblages.

Twenty $\mathrm{cm}^{3}$ of each sample was washed using $1 \mathrm{~mm}$ and $0.036 \mathrm{~mm}$ sieves. The $0.036-1 \mathrm{~mm}$ fractions were air dried $\left(20-30{ }^{\circ} \mathrm{C}\right)$. The dried residuum of the washed sample does not contain organic tests due to their destruction during laboratory preparation, which makes the sample comparable to fossil assemblages (Scott et al. 2001). Staining methods for distinguishing dead and live populations were not applied because the whole study was focused on determination of total populations, integrated during the period of accumulation of the sampled sediment layer. Thecamoebians have rapid generation time so total populations provide a better estimate than living populations of the seasonal standing crop (Scott \& Medioli 1980, Patterson \& Kumar 2000b).

Thecamoebians were identified using an optical stereomicroscope MBC-10 (56x). Test morphology was assesed and measurements were made using a stereomicroscope Olympus SZX 12 (144x) and scanning electron microscope (SEM) JEOL JSM - 6380LV, micrographs of thecamoebians were also taken. All facilities are located in the Department of Geology and Paleontology, Charles University in Prague.

Relative abundance of thecamoebians in the samples were expressed as number of specimens in $20 \mathrm{~cm}^{3}$ of the wet sediment. If the sample was rich in thecamoebians, the washed residual was divided into subsamples using a dry microsplitter, so that for counting purposes about 100-200 specimens were present in the subsample (Table 2).

The Shannon index of diversity was determined for each assemblage to express its diversity. It was defined as $\mathrm{SID}=-\sum \mathrm{p}_{\mathrm{i}} * \ln \left(\mathrm{p}_{\mathrm{i}}\right)$, where $\mathrm{p}_{\mathrm{i}}$ is the proportion of the $\mathrm{i}^{\text {th }}$ species in the assemblage (Patterson \& Kumar 2000).

Thecamoebians assemblages were classified through cluster analysis using the STATISTICA software. (Tree Clustering using Ward's method and Euclidean distance as a type of distance measure.) The entrance data included percentual representation of species in each sample assemblage and overall abundance of assemblage (samples with no assemblage were eliminated).

\section{Results}

In three cases (samples PL34/02, PL35/02 from PL and CT57/02 from CT) the same locality was sampled twice or three times at distances of 5-10 cm from each other to determine possible variability of the assemblages (Fig. 3). Analysis of these samples supports the conclusions published in 
Table 2. Water depth, distance from the actual shore line, type of sediment, abundance of thecamoebians in $20 \mathrm{~cm}^{3}$ of wet sediment and determinated species found in each sample (as a percentage). $\bullet$ A - lake. $\bullet \mathrm{B}$ - locality. $\bullet \mathrm{C}$ - sample. $\bullet \mathrm{D}$ - depth below water surface $(\mathrm{cm}) \cdot \bullet \mathrm{E}-$ distance from the shore line $(\mathrm{cm}) . \bullet \mathrm{F}-$ type of sediment. $\bullet \mathrm{G}-$ Centropyxis aculeata (Ehrenberg, 1832). $\bullet \mathrm{H}-$ Centropyxis arcula (Leidy, 1879). $\bullet \mathrm{I}-$ Centropyxis constricta (Ehrenberg, 1843). • J - Centropyxis orbicularis Deflandre, 1929.・K - Difflugia globulus (Ehrenberg, 1848). ・ L - Difflugia oblonga Ehrenberg, 1832. - M - Difflugia protaeiformis Lamarck, 1816. • N - Difflugia viscidula Penard, 1902.・ O - Euglypha acanthopora (Ehrenberg, 1841). • P - Nebela dentistoma Penard, $1890 . \bullet \mathrm{Q}-$ Nebela vitraea Penard, $1899 . \bullet \mathrm{R}-$ Pontigulasia compressa (Carter, 1864$)$. $\bullet \mathrm{S}-$ number of specimens per $20 \mathrm{~cm}{ }^{3}$ of wet sediment. $\bullet \mathrm{T}-$ Shannon index of diversity. $\bullet \mathrm{U}-$ number of species.

\begin{tabular}{|c|c|c|c|c|c|c|c|c|c|c|c|c|c|c|c|c|c|c|c|}
\hline A & $\mathrm{B}$ & $\mathrm{C}$ & $\mathrm{D}$ & $\mathrm{F}$ & G & $\mathrm{H}$ & I & $\mathrm{J}$ & $\mathrm{K}$ & $\mathrm{L}$ & $\mathrm{M}$ & $\mathrm{N}$ & $\mathrm{O}$ & $\mathrm{P}$ & Q & $\mathrm{R}$ & $\mathrm{S}$ & $\mathrm{T}$ & $\mathrm{U}$ \\
\hline \multirow{11}{*}{ 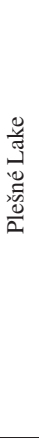 } & PL34 & PL34/02a & 10 & 100 sandy clay & 0 & 0 & 0 & 1 & 97 & 3 & 0 & 0 & 0 & 0 & 0 & 0 & 17550 & 0.2 & 3 \\
\hline & PL34 & PL34/02b & 10 & 100 sandy clay & 0 & 0 & 0 & 2 & 93 & 4 & 0 & 0 & 0 & 0 & 0 & 0 & 15686 & 0.3 & 3 \\
\hline & PL35 & PL35/02a & 50 & 200 silty clay & 0 & 0 & 0 & 5 & 95 & 0 & 1 & 0 & 0 & 0 & 0 & 0 & 2800 & 0.2 & 3 \\
\hline & PL35 & PL35/02b & 50 & 200 silty clay & 0 & 0 & 0 & 4 & 96 & 0 & 0 & 0 & 0 & 0 & 0 & 0 & 1960 & 0.2 & 2 \\
\hline & PL35 & PL35/02c & 50 & 200 silty clay & 0 & 0 & 0 & 4 & 96 & 0 & 0 & 0 & 0 & 0 & 0 & 0 & 2277 & 0.2 & 2 \\
\hline & PL36 & PL36/02 & 1540 & $>50 \%$ of organic material & 0 & 0 & 0 & 0 & 0 & 0 & 0 & 0 & 0 & 0 & 0 & 0 & 0 & 0 & 0 \\
\hline & PL37 & PL37/02 & 75 & 400 silty clay & 0 & 0 & 0 & 0 & 83 & 17 & 0 & 0 & 0 & 0 & 0 & 0 & 4064 & 0.5 & 2 \\
\hline & PL38 & PL38/02 & 1030 & 1500 silty clay & 0 & 11 & 0 & 29 & 59 & 0 & 2 & 0 & 0 & 0 & 0 & 0 & 416 & 1 & 4 \\
\hline & PL39 & PL39/02 & 10 & 200 sandy clay & 0 & 2 & 2 & 12 & 66 & 13 & 6 & 0 & 0 & 0 & 0 & 0 & 21800 & 1.1 & 6 \\
\hline & PL40 & PL40/02 & 75 & 300 sand and gravel & 0 & 1 & 0 & 0 & 92 & 4 & 0 & 2 & 0 & 0 & 0 & 0 & 195 & 0.3 & 4 \\
\hline & PL41 & PL41/02 & 40 & 300 sandy clay & 0 & 0 & 0 & 0 & 90 & 10 & 0 & 0 & 0 & 0 & 0 & 0 & 2619 & 0.3 & 2 \\
\hline \multirow{8}{*}{ 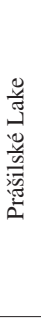 } & PR42 & PR42/02 & 40 & 100 sand and gravel & 0 & 0 & 0 & 9 & 74 & 10 & 6 & 0 & 0 & 0 & 0 & 0 & 1757 & 0.8 & 4 \\
\hline & PR43 & PR43/02 & 25 & 100 sand and gravel & 0 & 0 & 0 & 0 & 97 & 3 & 0 & 0 & 0 & 0 & 0 & 0 & 6140 & 0.1 & 2 \\
\hline & PR44 & PR44/02 & 1000 & sand and gravel & 0 & 5 & 2 & 13 & 11 & 59 & 11 & 0 & 0 & 0 & 0 & 0 & 578 & 1.3 & 6 \\
\hline & PR45 & PR45/02 & 5 & 50 sand and gravel & 0 & 0 & 5 & 0 & 88 & 7 & 0 & 0 & 0 & 0 & 0 & 0 & 252 & 0.4 & 3 \\
\hline & PR46 & PR46/02 & 200 & 200 sandy clay & 0 & 1 & 2 & 4 & 60 & 29 & 4 & 0 & 0 & 0 & 2 & 0 & 12369 & 1.1 & 7 \\
\hline & PR47 & PR47/02 & 70 & $30>50 \%$ of organic material (needles), silty clay & 0 & 27 & 0 & 14 & 45 & 9 & 5 & 0 & 0 & 0 & 0 & 0 & 44 & 1.3 & 5 \\
\hline & PR48 & PR48/02 & 120 & 300 silty clay & 0 & 3 & 1 & 2 & 43 & 51 & 0 & 0 & 0 & 0 & 0 & 0 & 765 & 0.9 & 5 \\
\hline & PR49 & PR49/02 & 330 & 1500 silty clay & 0 & 0 & 0 & 0 & 61 & 27 & 11 & 1 & 0 & 0 & 0 & 0 & 1480 & 0.9 & 4 \\
\hline \multirow{11}{*}{ 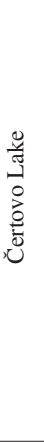 } & CT50 & CT50/02 & 50 & 150 sand and gravel & 0 & 1 & 0 & 0 & 91 & 8 & 0 & 0 & 0 & 0 & 0 & 0 & 34980 & 0.3 & 3 \\
\hline & CT51 & CT51/02 & 650 & 400 sand and gravel & 0 & 0 & 0 & 4 & 62 & 34 & 0 & 0 & 0 & 0 & 0 & 0 & 578 & 0.8 & 3 \\
\hline & CT52 & CT52/02 & 160 & 200 sandy clay & 0 & 0 & 0 & 2 & 78 & 14 & 6 & 0 & 0 & 0 & 0 & 0 & 6688 & 0.7 & 4 \\
\hline & CT53 & CT53/02 & 30 & 150 sandy clay & 0 & 3 & 3 & 2 & 81 & 13 & 0 & 0 & 0 & 0 & 0 & 0 & 2598 & 0.7 & 5 \\
\hline & CT54 & CT54/02 & 140 & 500 silty clay & 0 & 6 & 0 & 2 & 59 & 3 & 4 & 0 & 0 & 0 & 0 & 26 & 1442 & 1.1 & 6 \\
\hline & CT55 & CT55/02 & 15 & 200 sandy clay & 0 & 3 & 0 & 21 & 48 & 13 & 4 & 0 & 2 & 0 & 0 & 9 & 5554 & 1.5 & 7 \\
\hline & CT56 & СТ56/02 & 20 & 20 sand and gravel & 0 & 0 & 0 & 0 & 97 & 0 & 0 & 0 & 0 & 0 & 0 & 3 & 820 & 0.1 & 2 \\
\hline & CT57 & CT57/02a & 125 & 800 silty clay & 0 & 1 & 0 & 3 & 58 & 1 & 5 & 0 & 0 & 0 & 0 & 33 & 2260 & 1 & 6 \\
\hline & CT57 & CT57/02b & 125 & 800 silty clay & 0 & 0 & 0 & 4 & 55 & 5 & 5 & 0 & 0 & 0 & 0 & 30 & 1520 & 1.1 & 5 \\
\hline & CT58 & CT58/02 & 10 & 200 sand and gravel & 1 & 5 & 0 & 20 & 31 & 3 & 17 & 0 & 0 & 0 & 0 & 22 & 539 & 1.6 & 7 \\
\hline & CT59 & CT59/02 & 150 & 600 silty clay & 0 & 0 & 0 & 0 & 66 & 5 & 1 & 0 & 0 & 0 & 0 & 28 & 13917 & 0.8 & 4 \\
\hline \multirow{10}{*}{ 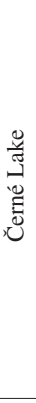 } & CN60 & $\mathrm{CN} 60 / 02$ & 20 & 400 sandy clay & 0 & 5 & 0 & 22 & 62 & 9 & 0 & 0 & 0 & 0 & 1 & 1 & 4713 & 1.1 & 6 \\
\hline & CN61 & CN61/02 & 150 & $1000>50 \%$ of organic material & 0 & 0 & 0 & 0 & 100 & 0 & 0 & 0 & 0 & 0 & 0 & 0 & 116 & 0 & 1 \\
\hline & CN62 & CN62/02 & 980 & silty clay & 0 & 0 & 0 & 0 & 67 & 5 & 0 & 7 & 0 & 0 & 0 & 21 & 9592 & 0.9 & 4 \\
\hline & CN63 & CN63/02 & 70 & 200 sandy clay & 0 & 2 & 0 & 24 & 64 & 7 & 0 & 0 & 0 & 0 & 0 & 3 & 1877 & 1 & 5 \\
\hline & CN64 & $\mathrm{CN} 64 / 02$ & 30 & $150>50 \%$ of organic material (needles), sand and gravel & 0 & 2 & 0 & 14 & 73 & 10 & 1 & 0 & 0 & 0 & 0 & 0 & 2128 & 0.8 & 5 \\
\hline & CN65 & CN65/02 & 20 & $1500>50 \%$ of organic material & 0 & 0 & 0 & 0 & 0 & 0 & 0 & 0 & 0 & 0 & 0 & 0 & 0 & 0 & 0 \\
\hline & CN66 & CN66/02 & 110 & 250 silty clay & 0 & 3 & 0 & 34 & 41 & 22 & 2 & 0 & 0 & 0 & 0 & 0 & 4524 & 1.2 & 5 \\
\hline & CN67 & CN67/02 & 40 & 100 sand and gravel & 0 & 0 & 0 & 4 & 93 & 2 & 1 & 0 & 0 & 0 & 0 & 0 & 1365 & 0.3 & 4 \\
\hline & CN68 & CN68/02 & 1320 & silty clay & 0 & 3 & 0 & 2 & 94 & 2 & 0 & 0 & 0 & 0 & 0 & 0 & 640 & 0.3 & 4 \\
\hline & CN69 & CN69/02 & 50 & $600>50 \%$ of organic material (needles), silty clay & 0 & 2 & 0 & 6 & 70 & 15 & 8 & 0 & 0 & 0 & 0 & 0 & 446 & 1 & 5 \\
\hline \multirow{6}{*}{ 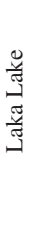 } & LA70 & LA70/02 & 40 & 150 silty clay & 16 & 0 & 0 & 0 & 39 & 11 & 13 & 19 & 0 & 0 & 0 & 1 & 3007 & 1.5 & 6 \\
\hline & LA71 & LA71/02 & 100 & $300>50 \%$ of organic material (vegetation), silty clay & 7 & 1 & 0 & 0 & 48 & 18 & 9 & 3 & 0 & 0 & 0 & 15 & 404 & 1.5 & 7 \\
\hline & LA72 & LA72/02 & 290 & $>50 \%$ of organic material & 1 & 0 & 0 & 0 & 78 & 5 & 1 & 3 & 0 & 0 & 0 & 12 & 98 & 0.8 & 6 \\
\hline & LA73 & LA73/02 & 5 & 30 sandy clay & 6 & 1 & 0 & 11 & 15 & 15 & 22 & 0 & 0 & 0 & 0 & 31 & 1802 & 1.7 & 7 \\
\hline & LA74 & LA74/02 & 55 & 600 silty clay & 1 & 9 & 0 & 36 & 4 & 21 & 2 & 7 & 0 & 0 & 0 & 19 & 229 & 1.7 & 8 \\
\hline & LA75 & LA75/02 & 40 & 600 silty clay & 0 & 2 & 0 & 4 & 29 & 12 & 9 & 30 & 0 & 3 & 0 & 11 & 2888 & 1.7 & 8 \\
\hline
\end{tabular}




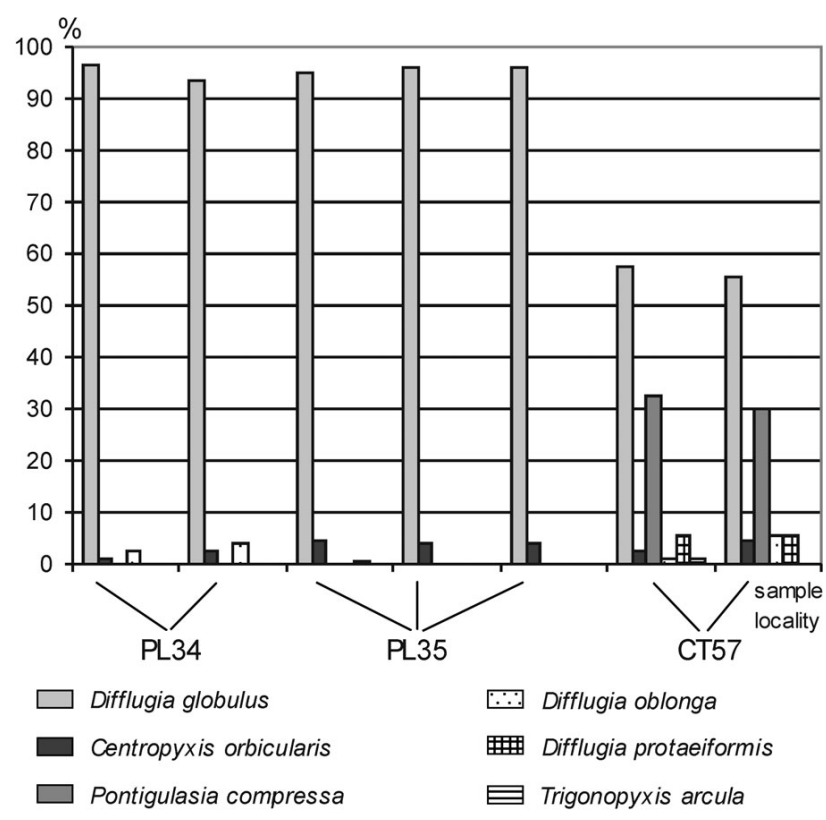

Figure 3. Similarity of species composition in samples collected within small distances $(5-10 \mathrm{~cm})$ in three localities (Plešné Lake - PL34, PL35, Čertovo Lake - CT57)

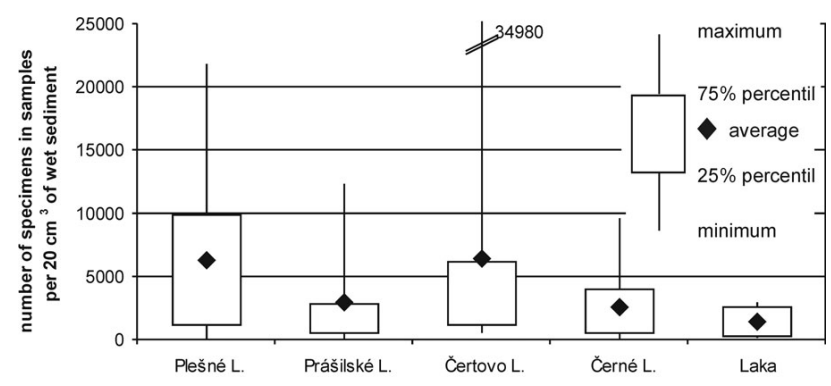

Figure 4. Abundance of thecamoebians in studied lakes.

the study by Holcová \& Lorencová (2004a) that no substantial differences in assemblage composition appear within a distance of 5-10 cm. The Shannon index of diversity (SDI) for these assemblages is similar within the same localities (0.2-0.3 for two samples from PL34, 0.2 for all three samples from PL35 and 1-1.1 for two samples from CT57) (see Table 2).

\section{Species composition and abundance in lakes}

Altogether, twelve thecamoebian species were determined in the studied material (Table 2). The species Difflugia globulus is present in practically all assemblages (in $96 \%$ of the samples), Difflugia oblonga occurs in $83 \%$ and Centropyxis orbicularis was identified in $65 \%$ of the samples. The numbers of species per sample varied from zero to eight. The lowest number of species was observed in PL (from
0 to 6 species per sample, on average 3 species per sample), the highest number of species is typical for LA (from 6 to 8 species per sample, 7 species on average). There are 4 species on average in $\mathrm{CN}$ (minimum 0, maximum 6 species per sample) and 5 species in CT (minimum 2 and maximum 7 species per sample) and in PR (from 2 to 7 species per sample).

The lowest average thecamoebian abundance was found in LA with 1405 specimens on average in $20 \mathrm{~cm}^{3}$ of wet sediment (minimum 98 specimens in a sediment with $>50 \%$ content of organic matter; maximum 3007 specimens in a silty clay sediment; the abundance of assemblages depends on the type of sediment generally, see further). A high value for average thecamoebian abundance is characteristic for PL (6306 specimens $/ 20 \mathrm{~cm}^{3}$ of wet sediment on average, minimum 0 in sediment with $>50 \%$ of organic matter content, and maximum of 21800 specimens in sandy clay sediment). Similarly, the assemblages from CT had 6445 specimens $/ 20 \mathrm{~cm}^{3}$ of wet sediment on average, with a minimum of 539 and maximum of 34980 specimens, both from sand and gravel). Here the highest number of specimens in an individual sample was found (sample CT50/02) (Fig. 4). The assemblages from other lakes are of medium abundance (average values of specimens per $20 \mathrm{~cm}^{3}$ of wet sediment are 2923 for PR and 2540 for $\mathrm{CN}$ ).

The Shannon diversity index was calculated for each sample assemblage (see Table 2 and Fig. 5). Its average value is 0.4 in PL, 0.8 in CN, 0.9 in CT and PR and 1.5 in LA.

\section{Sediment type dependence of assemblage composition and species abundance}

The number of specimens is affected by the type of sediment. Sandy clay sediment represents the environment of the diversified and relatively abundant assemblages ( 8478 specimens in $20 \mathrm{~cm}^{3}$ of wet sediment on average, ranging from 1802 to $21800 ; 5$ species on average, minimum 2, maximum 7 ; see Table 3 and Figs 6, 7). However, the most abundant assemblage comes from sand and gravel (CT50/02) which is the type of sediment with variable abundance of assemblages ranging from 195 to 34980 specimens in $20 \mathrm{~cm}^{3}$ of wet sediment. The less abundant assemblages come from the organic matter-dominated sediment (with more than $50 \%$ organic matter; 405 specimens in $20 \mathrm{~cm}^{3}$ of wet sediment on average, ranging from 0 to 2128). The relationship between the type of sediment and the number of species cannot be estimated from this quantity of data (Fig. 7). No significant relationship between abundance or presence of species and the type of sediment was observed.

Only two samples without any thecamoebians were found (see Table 2, samples PL36/02 from PL, and 
CN65/02 from CN). Both samples are characterized by algal slime and coarse vegetation detritus (needles, leaves).

\section{Cluster analysis of assemblages}

Cluster analysis classified thecamoebian assemblages into three clusters (Fig. 8). They are characterized by the dominant species and their relative abundance, distribution in lakes and the depth of collected samples (Figs 9, 10).

1) Difflugia globulus cluster group assemblages with 66-100\% of Difflugia globulus, this species is accompanied mainly by Difflugia oblonga (7-17\%) or Centropyxis orbicularis (6-14\%). This cluster dominated in PL and CN (Fig. 9). It is completely absent in LA. This cluster contains the greatest number of samples ( 21 samples) and it is characterized by the lowest number of registered species (1-6 species, 3 on average).

2) Difflugia globulus diversified cluster includes assemblages with a lower content of Difflugia globulus (4-64\%) followed by several other species - Difflugia oblonga (3-59\%), Centropyxis orbicularis (2-35\%), Trigonopyxis arcula (2-27\%), Pontigulasia compressa (1-31\%), Difflugia protaeiformis (2-21\%), with 3 to 8 species in total. This cluster is found in all lakes, with the smallest abundance in PL (Fig. 9), the highest in PR and LA lakes (Fig. 9), where the majority of the assemblages are the most diversified (6-8 species, 7 species on average, altogether 9 different species). This cluster has the greatest species diversity with assemblages from samples from shallow depths $(5-100 \mathrm{~cm}$, average $42 \mathrm{~cm})$.

3) Difflugia globulus and Pontigulasia compressa transitional cluster contains assemblages with a medium percentage of Difflugia globulus (55-78\%) and a relatively higher amount of Pontigulasia compressa (12-32\%) in comparison with the other clusters. In this cluster the percentage of Difflugia oblonga is less than 5\%. The highest presence of this cluster is in CT (Fig. 9). These assemblages come from deeper water (water depth of $125-980 \mathrm{~cm}$, on average $302 \mathrm{~cm}$ ) and are not present at depths less than $1 \mathrm{~m}$ (Fig. 10). Samples of this cluster contain the highest number of specimens in $20 \mathrm{~cm}^{3}$ of wet sediment.
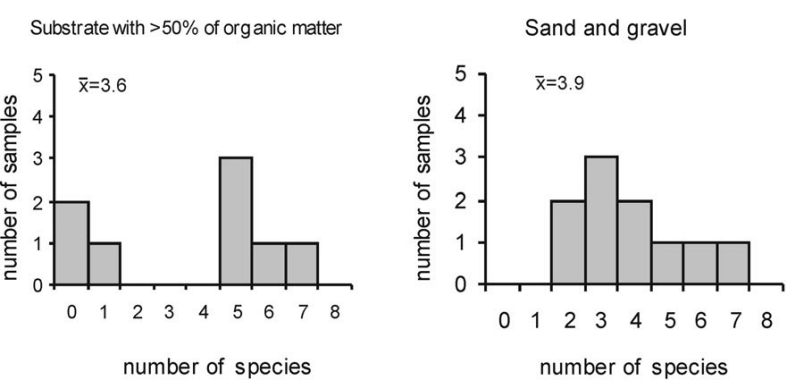

$\square$ Average

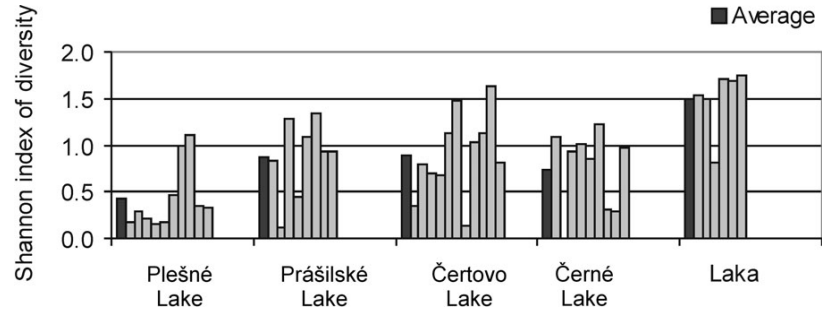

Figure 5. Shannon index of diversity for the samples from studied lakes.

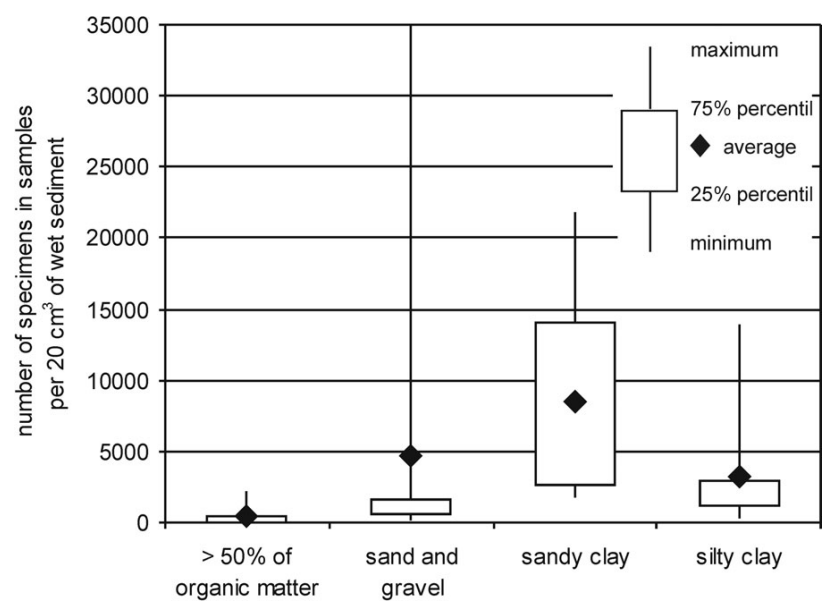

Figure 6. Abundance of thecamoebians in various types of sediment.

The SEM study showed that the species Difflugia oblonga was present in two distinct test size groups. The group of smaller specimens $(167 \times 88 \mu \mathrm{m}$ on average $)$ is almost three times greater in number than the group of larger ones $(289 \times 176 \mu \mathrm{m}$ on average). The larger specimens are present mainly in LA, less significantly in $\mathrm{CN}$. The average dimensions of the other individual species are included in the taxonomic section of this paper (see further).

\section{Classification of the lakes based on the thecamoebians fauna}

It is possible to classify the studied lakes into three categories, based on the thecamoebians fauna: 1) The strongly acidified PL with low diversificated assemblages and a do-
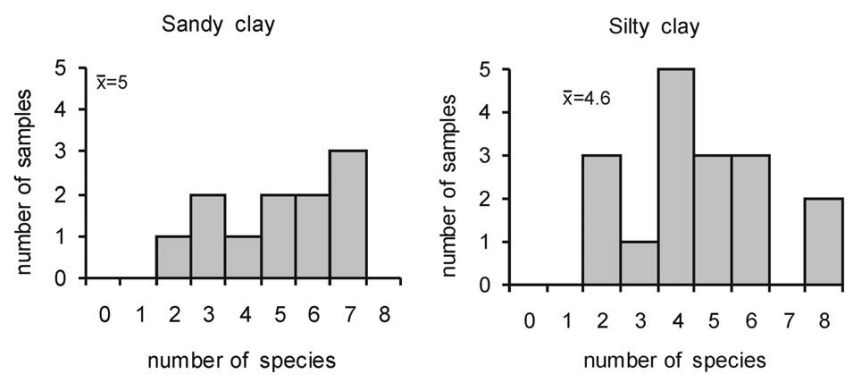

Figure 7. Number of samples from each types of sediment with various numbers of species. 
Table 3. Sediment type dependence of assemblage composition and species abundance.

\begin{tabular}{lrrrrrr}
\hline \multirow{2}{*}{ type of sediment } & \multicolumn{2}{c}{$\begin{array}{l}\text { abundance [specimens in } \\
20 \mathrm{~cm}^{3} \text { of wet sediment] }\end{array}$} & \multicolumn{2}{c}{ number of species } \\
\cline { 2 - 7 } & average & min. & max. & average & min. & max. \\
\hline sand and gravel & 4720 & 195 & 34980 & 4 & 2 & 7 \\
sandy clay & 8478 & 1802 & 21800 & 5 & 2 & 7 \\
silty clay & 3164 & 229 & 13917 & 5 & 2 & 8 \\
$\begin{array}{l}\text { substrate with }>50 \% \\
\text { of organic material }\end{array}$ & 405 & 0 & 2128 & 4 & 0 & 7 \\
\hline
\end{tabular}

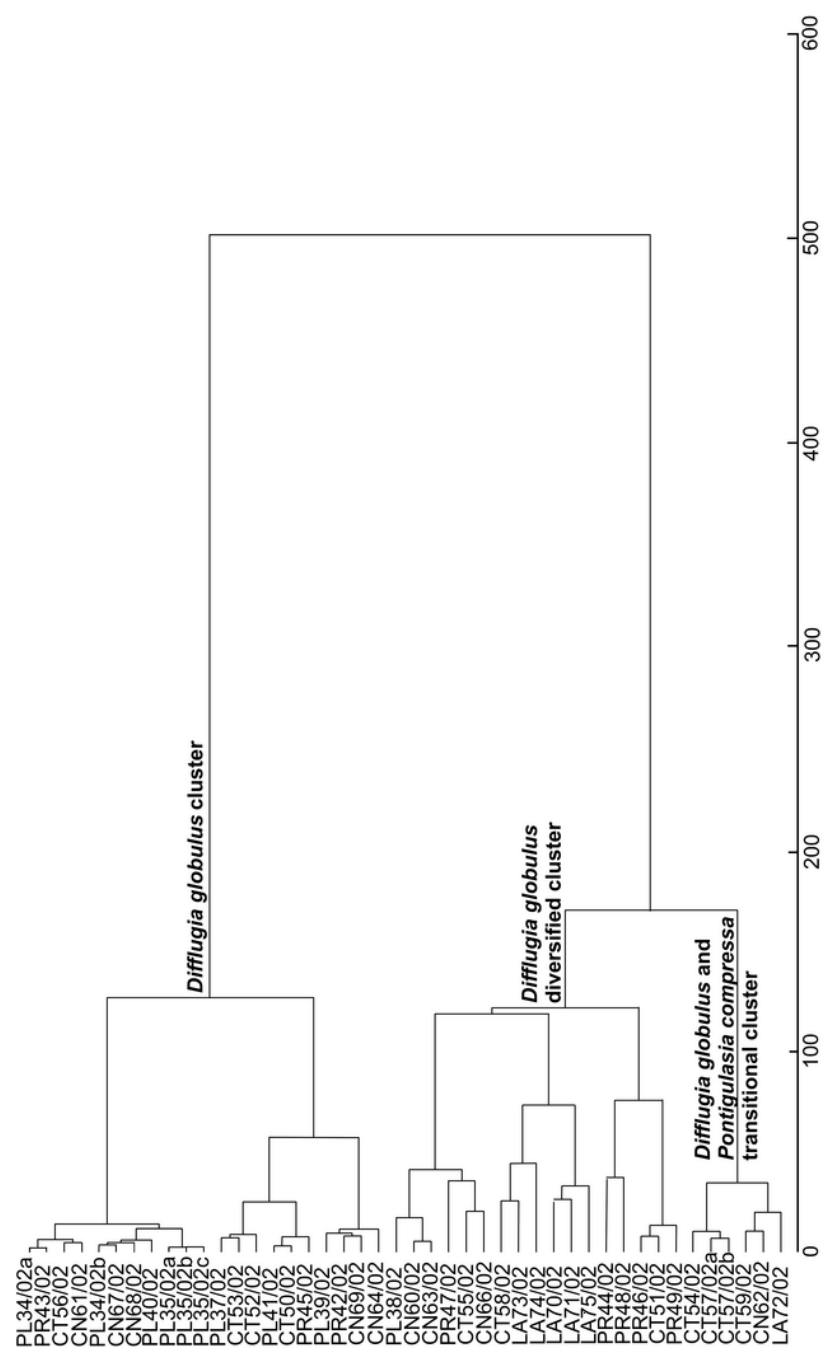

Figure 8. Results of cluster analysis (PL - Plešné Lake, CN - Černé Lake, CT - Čertovo Lake, PR - Prášilské Lake, LA - Laka Lake) (Tree Clustering using Ward's method and Euclidean distance as a type of distance measure)

minance of the species Difflugia globulus; 2) The shallow, partly overgrowing mesotrophic LA without water stratification hosts more diversified assemblages; 3) CN, PR and CT lakes with various types of assembleges, depending on the depth and type of sediment.

\section{Discussion}

\section{Comparison with the Frič \& Vávra (1898) study}

A comparison of the results of this study with the results of Frič \& Vávra (1898) shows (Table 4) that some new species have been found in CT (Euglypha acanthopora, Centropyxis aculeata, Trigonopyxis arcula, Centropyxis constricta, Centropyxis orbicularis, Pontigulasia compressa) as well as in CN (Centropyxis orbicularis, Difflugia viscidula, Nebela vitraea, Pontigulasia compressa). Some genera identified in this study were not reported in the 1898 study (Arcella vulgaris in both lakes, Centropyxis aculeata, Corythion dubium, Cyphoderia ampula, Difflugia urceolata, Euglypha ciliata, Nebela bohemica, Nebela collaris in CN). The results should be interpreted carefully, taking into account these facts: a) the methodology of the first study is not known; b) it seems that Frič and Vávra collected plenty of samples from the deep bottom while the present research was limited in this tendency (the majority of samples came from depths less than $150 \mathrm{~cm}$, only two samples came from deeper water); c) organic walled rhizopods are not considered here, d) variability that could be observed among samples within the same lake recently suggests that more samples could contain more species. Some species recently found (Trigonopyxis arcula, Difflugia globulus, Difflugia oblonga, Difflugia protaeiformis) are very similar, if we look at the taxonomic changes or corrections made since that time (1898), $c f$. Medioli \& Scott (1983).

\section{Ecological indicators of thecamoebian species}

Considering the most frequent occurrence of Difflugia globulus, Difflugia oblonga and Difflugia protaeiformis species, the conclusions of Scott et al. (2001), indicating the adaptability of these species to $\mathrm{pH}<6.2$ are in accordance with recent results. No similar indication of adaptability for the other common species, Centropyxis orbicularis and Pontigulasia compressa, to low $\mathrm{pH}$ was found in the literature.

Difflugia globulus - cold climatic indicator, relations to content of phytoplankton in water. - The frequent appearance of Difflugia globulus in all studied lakes could be explained by their high altitude (above $1000 \mathrm{~m}$ a.s.1.) and the relevant weather. It supports the hypothesis that Difflugia globulus is probably a good cool to cold climatic indicator (Collins et al. 1990).

High relative abundance of Difflugia globulus in PL (59-97\% of the assemblage, $87 \%$ on average) and the lowest abundance in LA (4-77\%, 35\% on average) could be interpreted as reflecting the content of phytoplankton in these lakes. According to Scott et al. (2001), this species feeds on green and yellow-green algae. PL contains phytoplankton 
which accounts for $70 \%$ of the total biomass (Nedbalová et al. 2006). On the other hand, a lower number of algal taxa and low content of phytoplankton in the biomass in comparison with other lakes has been found in LA (Nedbalová et al. 2006, Vrba et al. 2002, Vrba et al. 2003; see also Table 1). This could be a reason for lower abundace of Difflugia globulus. Nedbalová et al. (2006) noted that they did not observe any significant general change in phytoplankton biomass in their 2003 survey in comparison with the 1999 data. According to their results, the majority of phytoplankton species are probably able to adapt to changing $\mathrm{pH}$ and related factors and the qualitative phytoplankton structure in the mostly frequently investigated $\mathrm{CN}$ has remained surprisingly stable despite drastic changes in lake water chemistry within the last seven decades. Differences in the phytoplankton content in individual lakes, and simultaneously its stability in each lake, might cause a certain heterogeneity in thecamoebian assemblages that populated these lakes. Differences in representation of Difflugia globulus in the lakes that have been found in this study are in accordance with the above mentioned published data.

Difflugia oblonga - related to increasing organic content in substrate. - The species Difflugia oblonga is present in all samples from PR (3-9\%) and LA (5-21\%). Scott et al. (2001) note that it substitutes the species Difflugia globulus when the amount of organic content increases. This could be expected in LA which is overgrown by rich vegetation and contains a high quantity of organic sedimentary components. The explanation for the higher presence of Difflugia oblonga in PR is not clear. Lower Al concentration (Kohout \& Fott 2001, Vrba et al. 2006) and only moderate P limitation (Nedbalová et al. 2006) in comparison with other lakes could have some effect. According to the size of the tests it is possible to distinguish that the group of smaller specimens is almost three times greater in number than the group of larger ones. There are some suggestions found in literature (Bobrov et al. 1999, Scott et al. 2001) that the test size can be affected by nutrient conditions. The results of this study do not contradict these suggestions. Low temperature and oligotrophy of the studied lakes causing reduced availability of food could induce domination of smaller tests.

Difflugia protaeiformis - common in environments rich with organic matter. - Difflugia protaeiformis was found in all samples from LA (1-13\%), while in other lakes it occurs less frequently. Scott et al. (2001) note that it is well adapted to an environment rich in organic matter as is the environment of LA is to a great extent.

Pontigulasia compressa. - Medioli \& Scott (1988) remark that Pontigulasia compressa can adapt to any type of water environment. The results of this research could not confirm or reject this conclusion. There is a significant number of

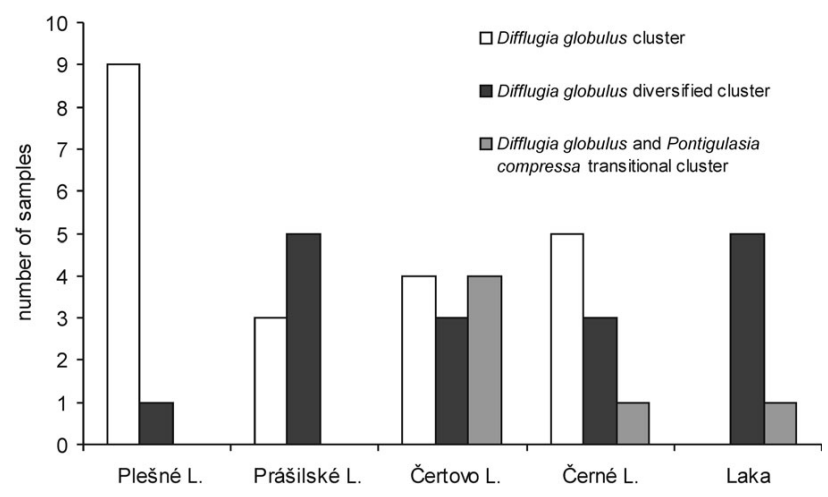

Figure 9. Representation of clusters in lakes (Tree Clustering using Ward's method and Euclidean distance as a type of distance measure).

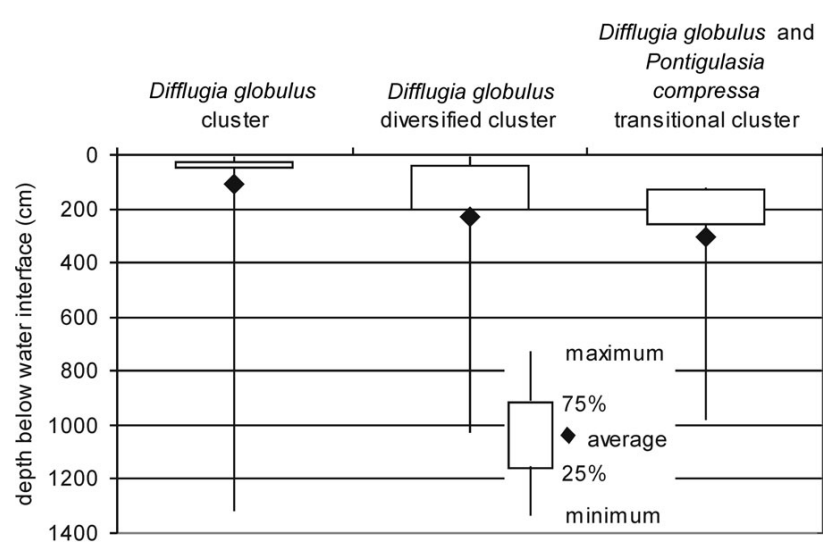

Figure 10. Depth of samples from various clusters.

this species in LA (1-31\%) but it was not found in PL and PR lakes. Holcová (2007) indicated that this species is associated with flowing water. In this study, the higher number of Pontigulasia compressa occur in LA where the water residence time in the lake is the shortest (Veselý 1996; see also Table 1).

Centropyxis orbicularis - uniform morphotype, abundant and represented in all lakes. - No essential data concerning ecology of Centropyxis orbicularis were found in the literature. However it occurs in $68 \%$ of all studied samples, its abundance in the assemblages is $10 \%$, on average. It is present in all lakes; no relationship with the type of sediment, environment, depth etc. was detected. Centropyxis orbicularis forms a substantial part of the diversified Difflugia globulus cluster where it constitutes 14-34\% of the assemblages. The morphotype of this species is quite invariable and it creates such a clearly separable group that there is the possibility that it could also be easily identified in older sediments and may have some ecological effects detectable in palaeoecology.

Centropyxis constricta-opportunistic character was neither proved, nor eliminated. - Regarding the species 
Table 4. Comparison of recently found thecamoebian species from Čertovo Lake and Černé Lake with data published in 1898 (Frič \& Vávra 1898), species comparison according to Mediolli \& Scott (1983).

\begin{tabular}{|c|c|c|}
\hline Lake & Frič \& Vávra (1898) & This study (2002) \\
\hline \multirow{10}{*}{$\begin{array}{l}\frac{0}{\tilde{J}} \\
\stackrel{\Xi}{0} \\
0 \\
0 \\
\stackrel{0}{0}\end{array}$} & Difflugia globulosa Duj. & Difflugia globulus (Ehrenberg, 1848) \\
\hline & Difflugia pyriformis Perty & Difflugia oblonga Ehrenberg, 1832 \\
\hline & Difflugia acuminata Ehbg. & Difflugia protaeiformis Lamarck, 1816 \\
\hline & & Euglypha acanthopora (Ehrenb., 1841) \\
\hline & & Trigonopyxis arcula (Leidy, 1879) \\
\hline & & Centropyxis aculaeta (Ehrenb., 1832) \\
\hline & & Centropyxis constricta (Ehrenb., 1832) \\
\hline & & Centropyxis orbicularis Deflandre, 1929 \\
\hline & & Pontigulasia compressa (Carter, 1864) \\
\hline & Arcella vulgaris Ehbg. & \\
\hline \multirow{16}{*}{ 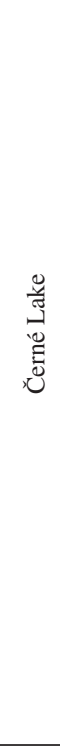 } & Difflugia pyriformis Perty & Difflugia oblonga Ehrenberg, 1832 \\
\hline & Difflugia acuminata Ehbg. & Difflugia protaeiformis Lamarck, 1816 \\
\hline & Difflugia globulosa Duj. & Difflugia globulus (Ehrenberg, 1848) \\
\hline & Difflugia urceolata Cor. & \\
\hline & & Difflugia viscidula Penard, 1902 \\
\hline & Difflugia arcula Leidy & Centropyxis arcula (Leidy, 1879) \\
\hline & Centropyxis aculeata St. & \\
\hline & & Centropyxis orbicularis Deflandre, 1929 \\
\hline & & Nebela vitraea Penard, 1899 \\
\hline & Nebela collaris Leidy & \\
\hline & Nebela bohemica Tar. & \\
\hline & & Pontigulasia compressa (Carter, 1864) \\
\hline & Euglypha ciliata Leidy & \\
\hline & Corythion dubium Tar. & \\
\hline & Cyphoderia ampula Leidy & \\
\hline & Arcella vulgaris Ehbg. & \\
\hline
\end{tabular}

Centropyxis constricta, Scott et al. (2001) indicate its tolerance to extreme conditions, they are often the first pioneer forms appearing in oligotrophic periglacial lakes, immediately after deglaciation. Patterson et al. (1996) added that the genus Centropyxis is opportunistic, it can withstand low temperatures, low nutrient content and oligotrophy. The opportunistic character of this species was confirmed in the study done in Šumava Mts in streams (Holcová 2007) and in the Lipno Reservoir near the inflow of the V1tava River (Holcová \& Lorencová 2004b) after the catastrophic flood events of 2002 and 2003. The appearance of this genus is not in contrary to the above mentioned data.
Centropyxis aculeata - oportune character was not proved, neither eliminated. - Information about Centropyxis aculeata species in the literaure is abundant and uniform. It is a typical r-strategy colonizer tolerating unfavourable environmental conditions, particularly lack of food (Collins et al. 1990, McCarthy et al. 1995) and low temperature (Charman 2001). This species is the first colonizer of coastal depressions evolving towards a freshwater status (Scott \& Medioli 1983). According to Scott et al. (2001) it is a good indicator of oligotrophy.

\section{Correlation of thecamoebian fauna correlates with phytoplankton content in the lakes}

Classification of the lakes based on the thecamoebian fauna correlates with biomass content, which is represented here mostly by phytoplankton content of the water (Nedbalová et al. 2006; see also Table 5). The highest biomass with high content of phytoplankton are characteristic for the strongly acidified PL (i.e., Type 1 lake, where the thecamoebian assemblages are not very diversified and Difflugia globulus reaches high relative abundance). Low content of phytoplankton occurs in the shallow, slowly overgrowing, mesotrophic LA (Type 2 lake, thecamoebian assemblages are more diversified, specimens of the species Difflugia oblonga reach greater sizes, $195-320 \mu \mathrm{m}$ in average). There are medium values for phytoplankton content in other lakes (Type 3 lakes, with various types of assembleges, depending on the sampling water depth and the type of sediment).

\section{Thecamoebian population in Šumava lakes compared with other lakes in the world}

The species composition of thecamoebian fauna in Šumava Mts lakes is quite similar to fauna from other lakes in the world. Species Difflugia protaeiformis, Difflugia oblonga, Pontigulasia compressa, Centropyxis aculeata, Centropyxis constricta constitute a more or less significant part of the lacustrine fauna (Scott \& Medioli 1983, Patterson et al. 1985, Patterson et al. 1996, Patterson \& Kumar 2000a, Dalby et al. 2000). Generally these species are typical for gyttja (Medioli \& Scott 1988).

A considerable difference is the dominance of Difflugia globulus species in the Šumava lakes and representation of

Figure 11. Difflugia globulus (Ehrenberg, 1848) from the south of the Czech Republic, Šumava Mts. • A, H, L, Q, Y - CT52/02 - Čertovo Lake, depth $160 \mathrm{~cm}$, sandy clay. • B, C, E - CN61/02, Černé Lake, depth $150 \mathrm{~cm}$, vegetable trash. • D, R, W - CN68/02, Černé Lake, depth $1320 \mathrm{~cm}$, silty clay. • F, J, K, N - PL37/02, Plešné Lake, depth 75 cm, silty clay with vegetable detritus mainly algae. • G, I, S - PR43/02, Prášilské Lake, depth 25 cm, sand and gravel. • M, O, P, T, U - Pl34/02, Plešné Lake, depth $10 \mathrm{~cm}$, sand to gravel, sandy sediment with needles. • V - PL41/02, Plešné Lake, depth $40 \mathrm{~cm}$, sandy clay with algal slime. $\bullet$ X - CT55/02, Čertovo Lake, depth $15 \mathrm{~cm}$, sand with vegetable detritus. $\bullet$ Z - CT57/02, Čertovo Lake, depth $125 \mathrm{~cm}$, silty clay. • A* - PL40/02, Plešné Lake, depth $75 \mathrm{~cm}$, sand and gravel with algal slime. • B* - CT53/02, Čertovo Lake, depth $30 \mathrm{~cm}$, sand and gravel. 


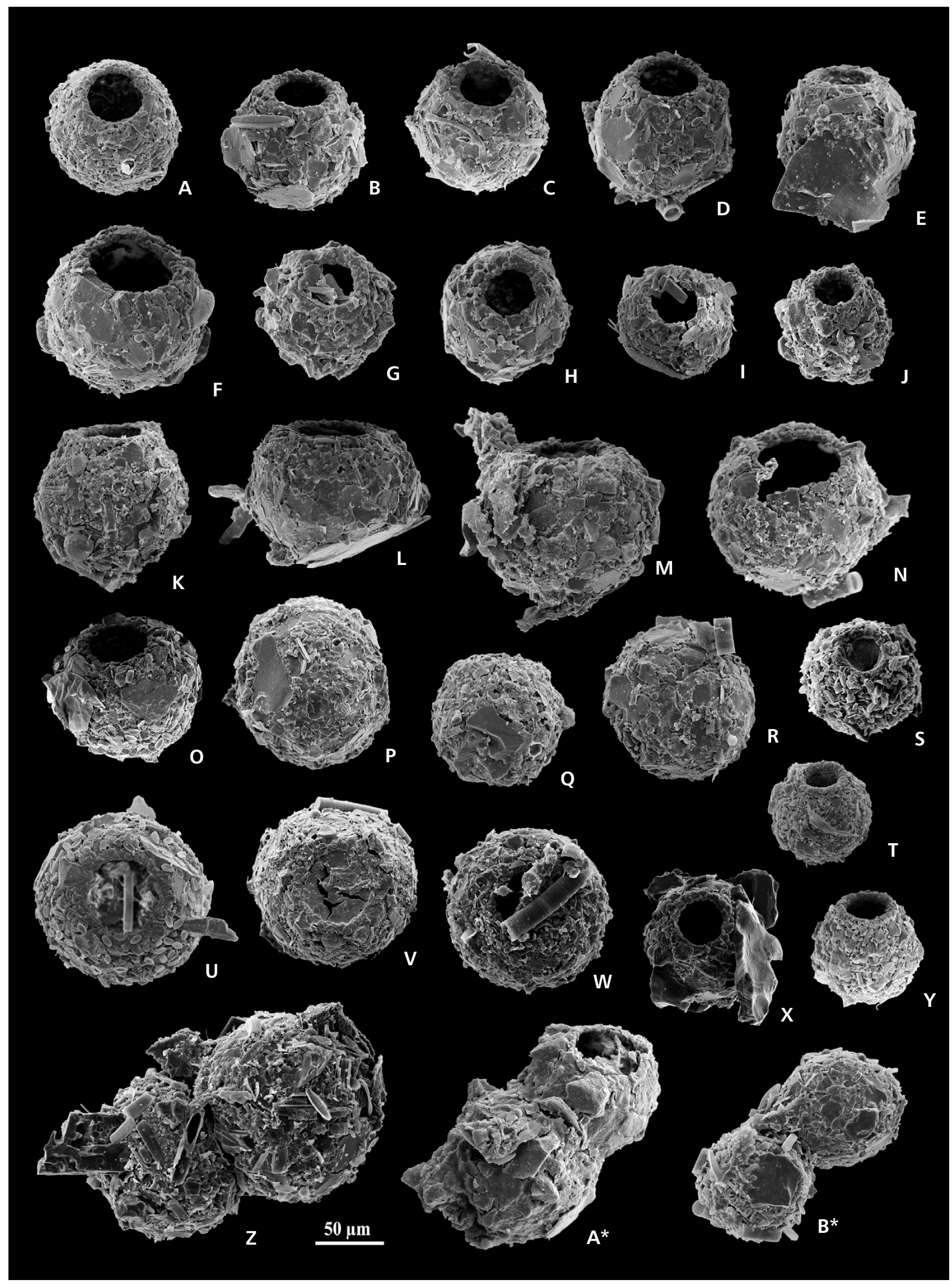


Table 5. Three groups of lakes and their characteristics.

\begin{tabular}{lll}
\hline Type of lake & Lake & Thecamoebian assemblage \\
\hline the highest biomass with high content of phytoplankton (70\%) & Plešné Lake & poor diversified, high relative abundance of Difflugia globulus \\
$\begin{array}{l}\text { low content of phytoplankton, shallow mesotrophic lake } \\
\text { slowly overgrowing by vegetation, without stratification }\end{array}$ & Laka Lake & $\begin{array}{l}\text { highly diversified, greater specimens of Difflugia oblonga } \\
(195-320 \mu \text { m in average })\end{array}$ \\
middle content of phytoplankton & $\begin{array}{l}\text { Prášilské Lake } \\
\text { Černé Lake } \\
\text { Čertovo Lake }\end{array}$ & various types of assemblages \\
& \\
\hline
\end{tabular}

Centropyxis orbicularis and Trigonopyxis arcula here. According to Medioli \& Scott (1988), the Difflugia globulus species is typical for lake sediment. Surprisingly, not many finds are recorded in the literature (e.g., Scott \& Medioli 1983, Patterson et al. 1996). The reports about two other species Trigonopyxis arcula and Centropyxis orbicularis are even more sporadic in lake environments (Gehrels et al. 2006).

Healthy thecamoebian faunas usually have Shannon index of diversity values higher than 2.0 (Patterson \& Kumar 2002) or approaching 2.5, and an abundance of about 500 specimens $/ \mathrm{cm}^{3}$ (Patterson \& Kumar 2000a). As in most stable climax communities, there is an equitable distribution of species in these healthy environments with no species overwhelmingly dominating the fauna (Patterson \& Kumar 2000a). Only a few assemblages in Šumava glacial lakes meet this boundary value of abundance (PL34/02 a PL39/02 from PL, PR46/02 from PR, CT50/02 a CT59/02 from $\mathrm{CT}$ and $\mathrm{CN} 62 / 02$ from $\mathrm{CN}$ ). No assemblage is so abundant in LA. The average value for thecamoebians abundance for the analyzed assemblages in the lakes are much lower. Common dominance of one or two species and low values of SDI (0.4-1.5) also indicate instability of the populations. It could be assumed that the stressing factor is the acidification of the lakes.

From the paleontological point of view, the important limnological parameters are mainly trophy, $\mathrm{pH}$ value of the water, abundance of phytoplankton and type of sediment. These variables may have some affect on thecamoebian assemblages as it is shown above.

\section{Conclusions}

Thirteen species of thecamoebians with anorganic tests were determined in 46 samples of recent sediments collected in 2002 from the bottoms of lakes in the Czech part of the Šumava Mts (Plešné, Černé, Čertovo, Prášilské and
Laka lakes). The most common species are Difflugia globulus (present in $96 \%$ of samples), Difflugia oblonga (in $83 \%$ of samples) and Centropyxis orbicularis (in $65 \%$ of samples). Number of species per sample varies from zero to eight.

Cluster analysis classified thecamoebian assemblages into three clusters. Their distribution according to the thecamoebian assemblages enables us to distinguish three groups within the five investigated lakes. This division corresponds to classification of the lakes according to biomass content which is represented here mostly by the phytoplankton content of the water:

- Plešné Lake, with low species richness and high relative abundance of Difflugia globulus; the lake contains the greatest biomass with a high content of phytoplankton (70\% of biomass ) and is strongly acidified;

- Laka Lake, with high species richness and the lowest relative abundance of Difflugia globulus, specimens of Difflugia oblonga reach greater sizes $(345 \mu \mathrm{m} \times 169 \mu \mathrm{m}$ on average); it is a shallow mesotrophic lake with the lowest phytoplankton biomass, slowly becoming overgrown by vegetation, without stratification, moderately acidified;

- Prášilské, Čertovo and Černé lakes, with various types of assemblage depending on the type of sediment and depth; phytoplankton content in these lakes attaining medium values;

The studied lakes are acidified to different degrees, all have $\mathrm{pH}$ values $<6$ yet. Therefore, all species of thecamoebians found should be adaptable to low $\mathrm{pH}$.

From the point of ecological demands on the observed species, Difflugia globulus seems to be a cold climate indicator with a positive relationship to the content of phytoplankton in lake water, Difflugia oblonga presence is related to increasing organic content in the substrate, represented mainly in LA and PR, and Difflugia protaeiformis is common in environments rich in organic matter. The possible opportunistic character of

Figure 12. Centropyxis orbicularis Deflandre, 1929 from the south of the Czech Republic, Šumava Mts. • A, B, P - CT58/02, Čertovo Lake, depth $10 \mathrm{~cm}$, sand and gravel. $\bullet$ C - PL39/02, Plešné Lake, depth $10 \mathrm{~cm}$, clayey sand with fine vegetable detritus. • D, L, R, S, U - PL38/02, Plešné Lake, depth $1030 \mathrm{~cm}$, silty clay with algal slime. • E, I, N - CT55/02, Čertovo Lake, depth $15 \mathrm{~cm}$, sand, vegetable detritus. • F, G, J, V - CT66/02, Černé Lake, depth $110 \mathrm{~cm}$, sandy clay, woody detritus. $\bullet$ H - LK74/02, Laka Lake, depth $55 \mathrm{~cm}$, silty clay with moss. $\bullet \mathrm{K}-$ PL55/02, Plešné Lake, depth $10 \mathrm{~cm}$, sandy clay with needles. $\bullet T-C N 60 / 02$, Černé Lake, depth $20 \mathrm{~cm}$, sandy clay with leaves. 


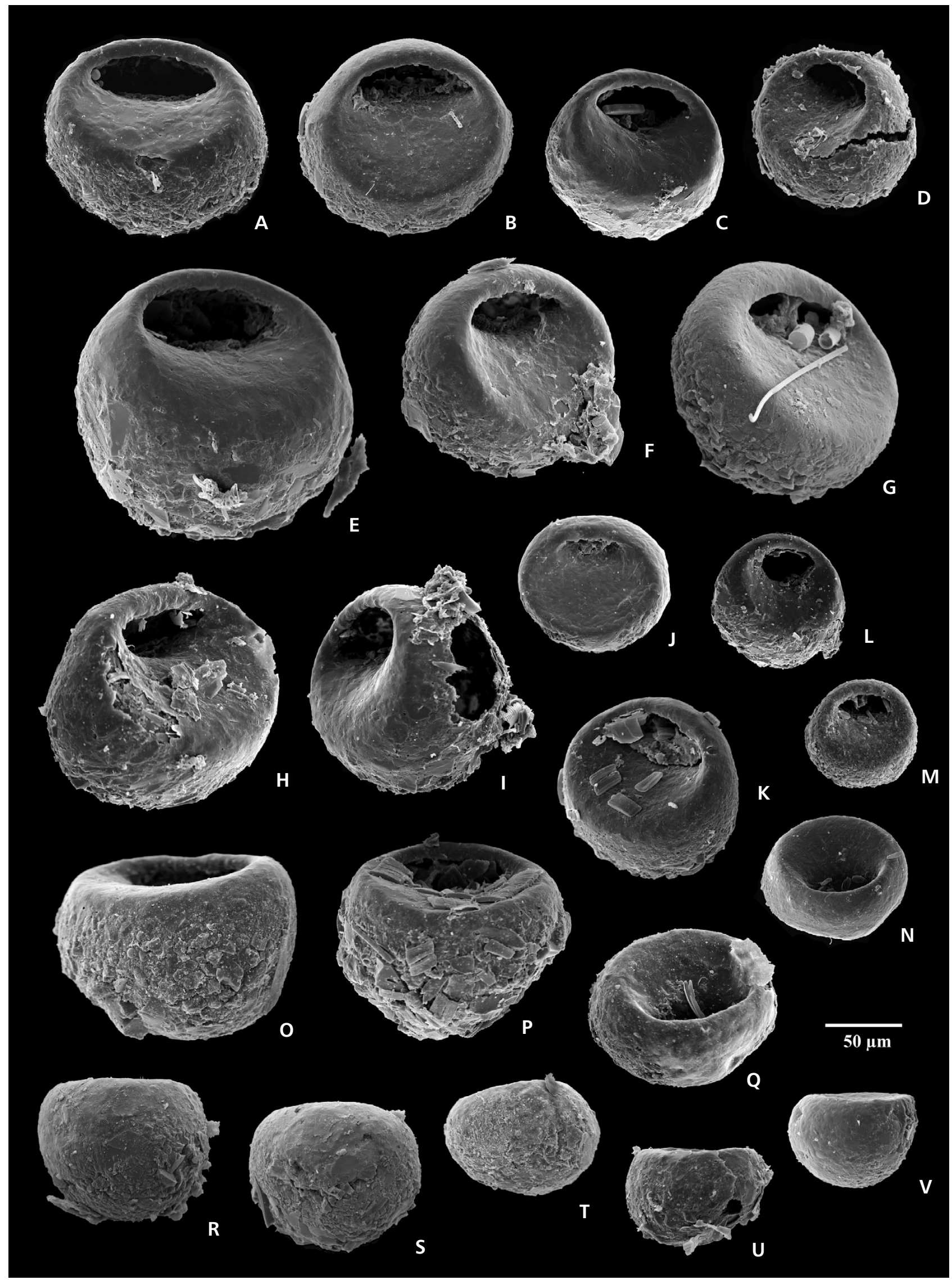


Centropyxis aculeata and Centropyxis constricta was neither proved, nor eliminated.

Centropyxis orbicularis occurs in $68 \%$ of the samples. It is present in all studied lakes, no dependance on the type of sediment, environment, depth etc. was detected. The morphotype of this species is quite invariable and creates a clearly separable group. This species could possibly be used in paleoecological considerations during studies of older sediments.

A comparison of the results of this study with the study done in 1898 shows that some new species have been found in CT (Euglypha acanthopora, Centropyxis aculeata, Trigonopyxis arcula, Centropyxis constricta, Centropyxis orbicularis, Pontigulasia compressa), as well as in CN (Centropyxis orbicularis, Difflugia viscidula, Nebela vitraea, Pontigulasia compressa). Some genera identified in this study were not reported in the 1898 study (Arcella vulgaris in CT and CN, Centropyxis aculeata, Corythion dubium, Cyphoderia ampula, Difflugia urceolata, Euglypha ciliata, Nebela bohemica, Nebela collaris in CN). Finds of other species (Trigonopyxis arcula, Difflugia globulus, Difflugia oblonga, Difflugia protaeiformis) are very similar, if we take into account the taxonomic changes or corrections made since that time (1898) according to Medioli \& Scott (1983).

From the paleontological point of view, the important limnological parameters discussed are mainly the lake trophy, $\mathrm{pH}$ value of the water, abundance of phytoplankton, and type of sediment. These variables may have some affect on thecamoebian assemblages as it is shown above.

\section{Taxonomic remarks}

The taxonomic approach described in the paper by Scott \& Medioli (1983) was followed in principle. They define several "natural-assemblages species" after a large study of their morphology and intragradational variants described in literature and observed in the field or in laboratory. Medioli \& Scott (1983) assumed that fossil assemblages are even more variable than living or subrecent assemblages collected at one particular point in time. In these taxonomical remarks, morphological variability of the species in the investigated material are described.

\section{Genus Difflugia Leclerc in Lamarck, 1816}

\section{Difflugia globulus (Ehrenberg, 1848) Figure 11}

The test is most often spherical, the size of measured specimens varies from $71 \mu \mathrm{m}$ to $138 \mu \mathrm{m}$ and the aperture width reaches $34-53 \%$ of test width. The test is covered by xenosomes of various sizes, sometimes by frustules of diatoms or enormous sand grains (Fig. 11X). Finer grains often border the aperture. Some specimens have the aperture closed by some epiphragm or some sort of plug that could be considered a cyst (see Fig. 11S, V). Some "conjoined twins" have been found (see Fig. 11Z-B*) that could be some part of the reproductive cycle, possibly parental and daughter tests.

\section{Difflugia oblonga Ehrenberg, 1832 \\ Figure 13S-W}

The test is oval and laterally compressed or pyriform mostly with a rounded fundus. Pyriform forms have mostly a clearly defined neck that could taper to the aperture. The aperture is oval or circular and surrounded by small particles. Sand grains cover the surface of the test. We could distinguish two groups of pyriform forms differing in size. Smaller specimens with a size of $167 \times 88 \mu \mathrm{m}$ on average and the larger ones that reached values $289 \times 176 \mu \mathrm{m}$ on average.

\section{Difflugia protaeiformis Lamarck, 1816 Figure 13M-R}

The shape of the test is an elongate oval, pyriform or ovoid mostly with a fundus ending in a terminal conical protube-

Figure 13. Thecamoebians from the south of the Czech Republic, Šumava Mts. • A-D - Trigonopyxis arcula (Leidy, 1879). A - CT54/02, Čertovo Lake, depth $140 \mathrm{~cm}$, silty clay. B - Lipno Reservoir Nová Pec, depth $60 \mathrm{~cm}$, silty clay. C - Lipno Reservoir, silty clay. D - Lipno Reservoir, sand. - E-H - Centropyxis aculeata (Ehrenberg, 1832). E - LA71/02, Laka Lake, depth $100 \mathrm{~cm}$, silty clay with > 50\% of organic matter. F, G - LA70/02, Laka Lake, depth $40 \mathrm{~cm}$, silty clay. H - LA73/02, Laka Lake, depth $5 \mathrm{~cm}$, sandy clay.・I-L - Centropyxis constricta (Ehrenberg, 1843). I - PR44/02, Prášilské Lake, depth $1000 \mathrm{~cm}$, sand and gravel. J - PL39/02, Plešné Lake, depth $10 \mathrm{~cm}$, sandy clay. K - CT55/02, Čertovo Lake, depth 15 cm, sandy clay. L - PR45/02, Prášilské Lake, depth $5 \mathrm{~cm}$, sand and gravel. • M-R - Difflugia protaeiformis Lamarck, 1816. M, N - LA73/02, Laka Lake, depth 5 cm, sandy clay. O - PR44/02, Prášilské Lake, depth 1000 cm, sand and gravel. P - CT55/02, Čertovo Lake, depth 15 cm, sandy clay. Q - CT57/02, Čertovo Lake, depth $125 \mathrm{~cm}$, silty clay. R - CN69/02, Černé Lake, depth $50 \mathrm{~cm}$, silty clay sediment with > 50\% organic matter (needles). • S-W - Difflugia oblonga Ehrenberg, 1832. S - PL34/02, Plešné Lake, depth $10 \mathrm{~cm}$, sandy clay. T - PR44/02, Prášilské Lake, depth 1000 cm, sand and gravel. U - LA71/0, Laka Lake, depth $100 \mathrm{~cm}$, silty clay with > 50\% organic matter. V - PL34/02, Plešné Lake, depth $10 \mathrm{~cm}$, sandy clay. W - LA72/02, Laka Lake, depth $290 \mathrm{~cm}$, algae, needles. - X, Y - Difflugia viscidula Penard, 1902. X - LA71/02, Laka Lake, depth $100 \mathrm{~cm}$, silty clay with > 50\% organic matter. Y - LA75/02, Laka Lake, depth $40 \mathrm{~cm}$, silty clay. $\bullet \mathrm{Z}, \mathrm{A} *$ - Pontigulasia compressa (Carter, 1864). Z - LA71/02, Laka Lake, depth 100 cm, silty clay with $>50 \%$ organic matter. A* - LA73/02, Laka Lake, depth $5 \mathrm{~cm}$, sandy clay. 


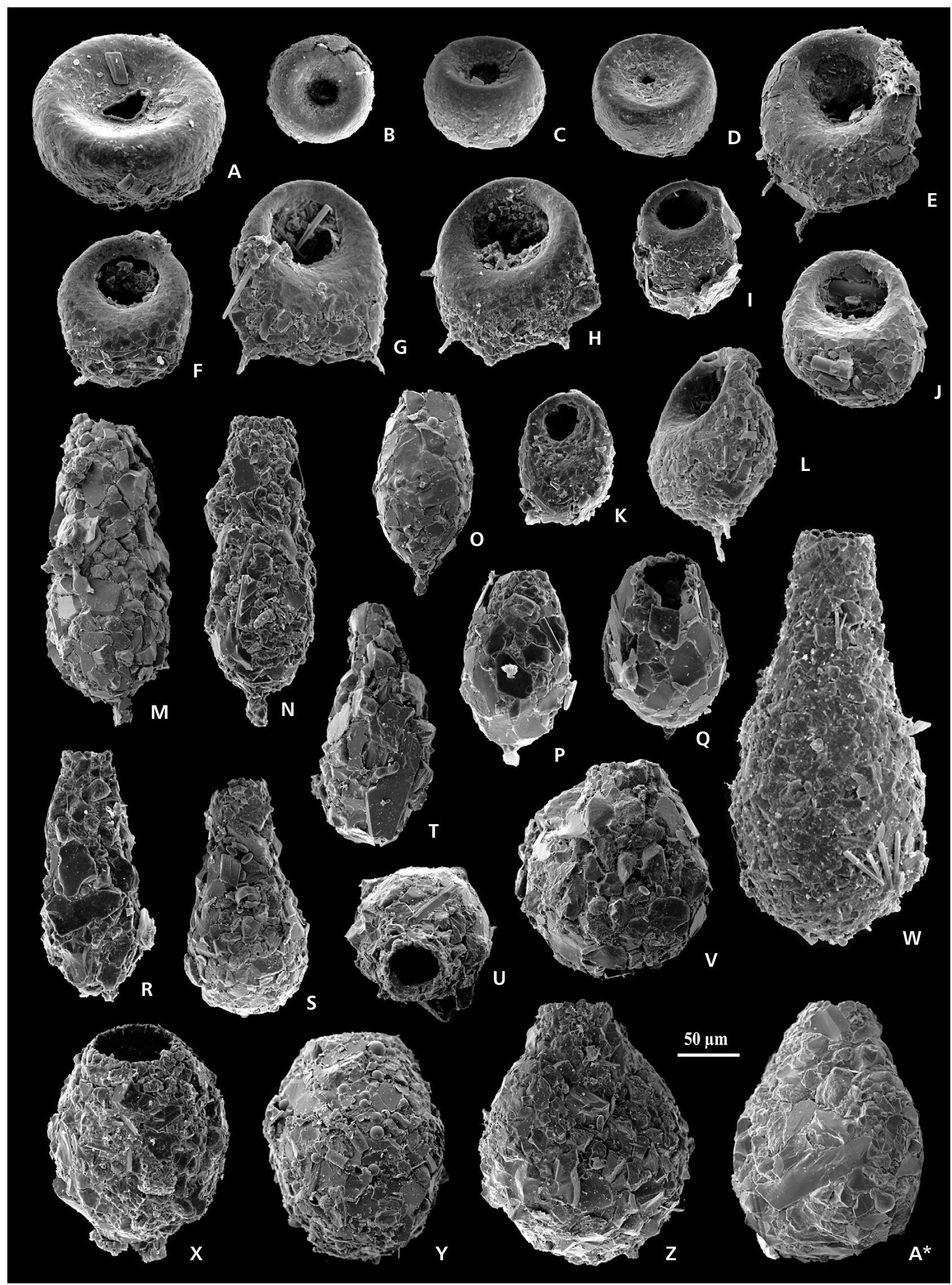


rance or horn. A neck could be present. The aperture is circular and surrounded by a rim of small grains. The test is created by sand particles. The size varies between 100 and $235 \mu \mathrm{m}$.

\section{Difflugia viscidula Penard, 1902}

Figure 13X, Y

The test morphology is relatively uniform in its ovoid shape. The aperture is circular and surrounded by small grains. The rest of the test is covered with sand grains of various sizes.

\section{Genus Centropyxis Stein, 1859}

Centropyxis aculeata (Ehrenberg, 1832) Figure 13E-H

The test is circular or ovoid and bilaterally symmetric from a dorsal view, in lateral view it is depressed and tapers anteriorly towards the aperture. The apertural side is large with a subcentral oval or circular invaginated aperture. The anterior angle (according to Medioli \& Scott 1983) is small. Several spines could be developed along the fundus or lateral margins. The rough dorsal side of the test is composed of sand grains, the ventral side is smoother and covered by organic matrix. The size mostly ranges from $90-155 \mu \mathrm{m}$.

\section{Centropyxis constricta (Ehrenberg, 1843) Figure 13I-L}

The test is elliptical from a dorsal view, slightly compressed and tapering anteriorly from a lateral view. The anterior angle is larger than in Centropyxis aculeata, the ventral side is small. The ratio of height : length is high (around 0.7 in several measured specimens). The aperture is usually large, invaginated, oval or circular in shape and is situated anteriorly. The test is created by sand particles of various sizes, the ventral side is smooth and covered by organic matrix. The size of the test is intermediate $(85-115 \mu \mathrm{m})$.

\section{Centropyxis orbicularis Deflandre, 1929} Figure 12A-V

The test is irregularly hemispherical; height of the fundus is the highest of species considered in this study. The test is circular in dorsal view. The large apertural side bears a slightly invaginated oval aperture in its anterior part; it is not rare to find arch-shape or crescent apertures. The dorsal side is curved along its whole length. The test is covered by xenosomes, rough ones on the dorsal side, on the apertural side the xenosomes are often likely to be overlapped by an autoge- nous product in order to produce a smoother surface. The size of measured specimens varies from 71 to $167 \mu \mathrm{m}$. The ratio between height and width of the aperture is $0.35-0.64$. It is not possible to measure the anterior angle because of the curved dorsal side. Height : length ratio is high (0.5-0.9).

\section{Genus Trigonopyxis Penard, 1912}

Trigonopyxis arcula (Leidy, 1879) Figure 13A-D

From a dorsal view the test is circular, laterally it is hemispherical and symmetrical. The apertural side is slightly invaginated and smoothly covered with organic matrix; the dorsal side is rough and created by sand grains. The aperture is central or subcentral, circular, triangular or irregular and usually surrounded by a small collar. Test diameter varies from 85 to $155 \mu \mathrm{m}$.

\section{Genus Pontigulasia Rhumbler, 1895}

\section{Pontigulasia compressa (Carter, 1864)} Figure 13Z, A*

Morphology of the large test (mostly above $200 \mu \mathrm{m}$ ) is relatively uniform, ovoid or pyriform and laterally compressed. A short neck tapers to the aperture and joins the body by a characteristic V-shaped constriction. The aperture is oval or circular. The rough surface of the test is produced by sand grains, the neck is usually smoother and produced by smaller particles.

\section{Acknowledgement}

This research was supported by grant project MSM0021620855. The author sincerely thanks K. Holcová for invaluable training during this research, also for her comments and support. Thanks also to V. Vajskebr and P. Čáp who helped with fieldwork. Gratefully acknowledged are the journal's reviewers A. Dallimore and T. Patterson for their valuable suggestions, and K. Žák for his helpful comments on the final version of the manuscript.

\section{References}

ALBRECHT, J. ed. 2003. Českobudějovicko, 808 pp. In MACKOVČIN, P. \& SEDLÁČEK, M. (eds) Chráněná území ČR, svazek VIII. Agentura ochrany přírody a krajiny ČR a Ekocentrum Brno, Praha.

ASIOLI, A. \& MEDIOLI, F.S. 1992. Ricostruzione dei paleoambienti attraverso le Tecamebe in alcuni laghi sudalpini (Orta, Varese e Candia). Atti X Congresso Associazione Italiana Oceanologia e Limnologia (Alassio, 4-6 novembre 1992), 487-501. 
Asioli, A., Medioli, F.S. \& PATterson, T. 1996. Thecamoebians as a tool for reconstruction of paleoenvironments in some Italian lakes in the foothills of the southern Alps (Orta, Varese and Candia). Journal of Foraminiferal Research 26(3), 248-263.

BALÍK, V. 1992. Krytenky (Rhizopoda, Testacea) ze Státní přírodní rezervace Trojmezná hora na Šumavě (ČSFR). Sborník Jihočeského muzea v Českých Budějovicích. Př́rodní vědy 32, 69-78.

BALÍK, V. \& SONG, B. 2000. Benthic freshwater testate amoebae assemblages (Protozoa: Rhizopoda) from Lake Dongting, People's Republic of China, with description of a new species from the Genus Collaripyxidia. Acta Protozoologica 39, 149-156.

BARTOŠ, E. 1949. Mikroskopická zvířena šumavských mechů. Mechy okolí Plešného jezera. Věstník Československé zoologické společnosti 13, 10-29.

BARTOŠ, E. 1951. Kořenonožci, vírníci a želvušky mechů šumavských předhoří. Časopis Národního muzea 11, 50-64.

Bobrov, A.A., CHARMAN, D.J. \& WARNER, B.G. 1999. Ecology of testate amoebae (Protozoa: Rhizopoda) of peatlands in Western Russia with special attention to niche separation in closely related taxa. Protist 150, 125-136.

BuRbIDGE, S.M. \& SCHRÖDER-ADAMS, C.J. 1998. Thecamoebians in Lake Winnipeg: a tool for Holocene paleolimnology. Journal of Paleolimnology 19, 309-328. DOI 10.1023/A:1007942301638

CARTER, H.J. 1864. On freshwater Rhizopoda of England and India. Annals and Magazine of Natural History, ser. 3(13), 18-39.

CHARMAN, D.J. 2001. Biostratigraphic and palaeoenvironmental applications of testate amoebae. Quaternary Science Reviews 20, 1753-1764. DOI 10.1016/S0277-3791(01)00036-1

COLlins, E.S., MCCARTHY, F.M.G., MEDIOLI, F.S., SCOTT, D.B. \& HÖNIG, C.A. 1990. Biogeographic distribution of modern thecamoebians in a transect along the eastern north American coast, 783-792. In HEMBLEDEN, C., KAMINSKI, M., KUHNT, W. \& SCOTT, D.B. (eds) Paleoecology, biostratigraphy, paleoceanography and taxonomy of agglutinated foraminifera. Kluwer Academic Publishers, Dordrecht.

DALby, A.P., Kumar, A., MoORE, J.M. \& PATterson, R.T. 2000. Preliminary survey of arcellaceans (Thecamoebians) as limnological indicators in tropical lake Sentani, Irian Jaya, Indonesia. Journal of Foraminiferal Research 30(2), 135-142. DOI $10.2113 / 0300135$

DALLIMORE, A., SCHRÖDER-ADAMS, C.J. \& DALlimore, S. 2000. Holocene environmental history of thermokarst lakes on Richards island, Northwest Territories, Canada: Thecamoebians as paleolimnological indicators. Journal of Paleolimnology 23, 261-283. DOI 10.1023/A:1008184522637

DeflandRe, G. 1929. Le genre Centropyxis Stein. Archiv für Protistenkunde 67, 322-375.

EHRENBERG, G.C. 1832. Über die Entwickelung und Lebensdauer der Infusionsthiere, nebst ferneren Beiträgen zu einer Vergleichung ihrer organischen Systeme. Königliche Akademie der Wissenschaften zu Berlin, Physikalische Abhandlungen (1831), 1-154.

EHRENBERG, G.C. 1843. Verbreitung und Einfluss des mikroskopischen Lebens in Süd- und Nord-Amerika. Abhandlungen der Königliche Akademie der Wissenschaften zu Berlin (1841), 291-446.

EHRENBERG, G.C. 1848. Fortgesetzte Beobachtungen über jetzt herrschende atmosphärische mikroskopische Verhältnisse. Bericht über die zur Bekanntmachung geeigneten Verhandlungen der
Königliche Preussischen Akademie der Wissenschaften zu Berlin 13, 370-381.

ELLISON, R.L. 1995. Paleolimnological analysis of Ullswater using testate amebas. Journal of Paleolimnology 13, 51-63.

DOI 10.1007/BF00678110

FOTT, J., KOHOUT, L. \& PRAŽÁKOVÁ, M. 2001. Zooplankton šumavských jezer: 130 let změn a perspektivy dalšího vývoje. Konference Aktuality šumavského výzkumu (Srní 2.-4.4. 2002), $58-59$.

FRIČ, A. \& VÁVRA, V. 1898. Výzkumy zvířeny ve vodách českých. III - Výzkum dvou jezer šumavských Černého a Čertova jezera. Archiv pro př́rodovědné prozkoumání Čech 10(3), 1-68.

GolemansKy, V. 1970. A list of testacea (Protozoa, Rhizopoda) from the Duszatynskie Lakes in Poland. Fragment faunistica 16, 21-25.

GolemAnsKY, V. 1973. Mote sur la faune thécamoebinne (Rhizopoda, Testacea) du Lac Morskie Oko en Tatras Polonaises. Izvestija na zoologičeskija Institut Sofia 38, 21-24.

HEJZLAR, J., KOPÁČEK, J., VRBA, J., ČížKOVÁ, R., KOMÁRKOVÁ, J. \& ŠIMEK, K. 1998. Limnological study of Plešné Lake in 1994-1995. Silva Gabreta 2, 155-174.

HolCOVÁ, K. 2007. Thecamoebians from the Upper Vltava River (Šumava Mountains, Czech Republic): species composition of assemblages vs. environment in streams. Journal of Foraminiferal Research 37(4), 287-299. DO1 10.2113/gsjfr.37.4.287

HolCOVÁ, K. \& LORENCOVÁ, M. 2004a. Thecamoebians from the Sumava Mountains - comparison of large scale and detailed variability of thecamoebians assemblages, 185-207. In BUBÍK, M. \& KAMInski, M.A. (eds) Proceedings of the Fifth International Workshop on Agglutinated Foraminifera, Grzybowski Foundation Special Publication 8.

HolCOVÁ, K. \& LORENCOVÁ, M. 2004b. Krytenky (Rhizopoda, Testacea) v nejmladších sedimentech Lipna - odraz srážkově výjimečných let 2002 a 2003, 104-109. In DVOŘÁK, L. \& ŠUSTR, P. (eds) Sborník z konference Aktuality šumavského výzkumu 2, Srní. Správa NP Šumava, Vimperk.

HöNIG, C.A. \& SCOTT, D.B. 1987. Postglacial stratigraphy and sea-level change in southwestern New Brunswick. Canadian Journal of Earth Sciences 24, 354-364.

JANSKÝ, B. \& ŠOBR, M. 2003. Jezera České republiky. 199 pp. Př́rodovědecká fakulta UK, katedra fyzické geografie a geoekologie, Praha.

KoHOUT, L. \& FOTT, J. 2001. Vertikální migrace zooplanktonu na Prášilském jezeře. Konference Aktuality šumavského výzkumu (Srní 2.-4. 4. 2002), 93-94.

KoPÁČEK, J., HEJZlAR, J., KAŇA, J. \& PORCAL, P. 2001. Faktory ovlivňující chemismus šumavských jezer. Konference Aktuality šumavského výzkumu (Srní 2.-4. 4. 2002), 63-66.

KopÁČEK, J., HeJZlaR, J., StUChlík, E., FOTT, J. \& VesElÝ, J. 1998. Reversibility of acidification of mountain lakes after reduction in nitrogen and sulphur emissions in Central Europe. Limnology and Oceanography 43(2), 357-361.

LAMARCK, J.B. 1816. Histoire naturelle des animaux sans vertebres. Tome 2. 568 pp. Verdière, Paris.

LEIDY, J. 1879. Fresh-water Rhizopods of North America. Report of the United States Geological Survey of the Territories 12, XI + $324 \mathrm{pp}$.

MAJER, V., KOPÁČEK, J. \& VeSElÝ, J. 2001. Modelování budoucího vývoje chemismu Plešného jezera. Konference Aktuality šumavského výzkumu (Srni 2.-4.4. 2002), 60-62. 
McCarthy, F.M.G., Collins, E.S., MCANDREWS, J.H., KeRR, H.A., SCOTT, D.B. \& MEDIOLI, F.S. 1995. A comparison of postglacial Arcellacean ("Thecamoebian") and pollen succession in Atlantic Canada, illustrating the potential of Arcellaceans for paleoclimatic reconstruction. Journal of Paleontology 69(5), 980-993.

MEDIOLI, F.S. \& SCOTT, D.B. 1988. Lacustrine thecamoebians (mainly Arcellaceans) as potential tools for palaeolimnological interpretations. Palaeogeography, Palaeoclimatology, Palaeoecology 62, 361-386. DOI 10.1016/0031-0182(88)90062-4

MEdioli, F.S., SCOTT, D.B., COLLINS, E.C. \& MCCARTHY, F.M.G. 1990. Fossil thecamoebians; present status and prospects for the future, 813-839. In HEMBLEDEN, C., KAMINSKI, M.A., KUHNT, W. \& SCOTT, D.B. (eds) Proceedings of the NATO Advanced Study Institute on Paleoecology, biostratigraphy, paleoceanography and taxonomy of agglutinated foraminifera NATO ASI Series. Series C: Mathematical and Physical Sciences 327.

NEDBALOVÁ, L. 2001. Druhové složení a biomasa fytoplanktonu sedmi šumavských jezer. Konference Aktuality šumavského výzkumu (Srní 2.-4.4. 2002), 67-69.

NedBAlovÁ, L., VRBA, J., FOTT, J., KOHOUT, L., KopÁČEK, J., MACEK, M. \& SOLDÁN, T. 2006. Biological recovery of the Bohemian Forest lakes from acidification. Biologia 61(20), S1-S13.

PATTERSON, R.T. \& KUMAR, A. 2000a. Assessment of arcellacean (thecamoebian) assemblages, species, and strains as contaminant indicators in James Lake, northeastern Ontario, Canada. Journal of Foraminiferal Research 30(4), 310-320. DOI 10.2113/0300310

PATTERSON, R.T., BARKER, T. \& BURBIDGE, S.M. 1996. Arcellaceans (Thecamoebians) as proxies of arsenic and mercury contamination in northeaster Ontario lakes. Journal of Foraminiferal Research 26(2), 172-183.

PATTERSON, R.T. \& KUMAR, A. 2000b. Use of Arcellacea (Thecamoebians) to gauge levels of contamination and remediation in industrially polluted lakes, 257-278. In MARTIN, R.E. (ed.) Environmental micropaleontology: the application of microfossils to environmental geology. Topics in geobiology 15.

PATterson, R.T., MACKINNON, K.D., SCOTT, D.B. \& MEDIOLI, F.S. 1985. Arcellaceans (Thecamoebians) in small lakes of New Brunswick and Nova Scotia: Modern distribution and Holocene stratigraphic changes. Journal of Foraminiferal Research 15(2), 114-137.

PENARD, E. 1902. Faune rhizopodique du bassin du Léman. 714 pp. Henry Kündig, Geneva.

RHUMBLER, L. 1895. Beiträge zur Kenntnis der Rhizopoden (Beitrag III, IV und V). Zeitschrift für Wissenschaftliche Zoologie 61(1), 38-110.

ROSA, K. 1958. Půdní kořenonožci boubínského pralesa. Ochrana přirody 13, 185-187.

SCOTT, D.B. \& MEDIOLI, F.S. 1980. Living vs. total foraminiferal populations: their relative usefulness in paleoecology. Journal of Paleontology 54, 814-831.

SCOTT, D.B. \& MEDIOLI, F.S. 1983a. Agglutinated rhizopods in Lake Erie: modern distribution and stratigraphic implications. Journal of Paleontology 57(4), 809-820.

ScotT, D.B. \& MEdioli, F.S. 1983b. Holocene Arcellacea (Thecamoebians) from eastern Canada. Cushman Foundation Foraminiferal Research Special Publication 21, 63.

SCOTT, D.B., MEDIOLI, F.S. \& SCHAFER, C.T. 2001. Monitoring in
Coastal Environments Using Foraminifera and Thecamoebian Indicators. $\mathrm{V}+168 \mathrm{pp}$. Cambridge University Press.

SCHÖNBORN, W. 1992. The Role of Protozoan Communities in Freshwater and Soil Ecosystems. Acta Protozoologica 31, 11-18.

STEIN, S.F.N. VON 1859. Über die ihm aus eigener Untersuchung bekannt gewordenen Süsswasser - Rhizopoden. Abhandlungen der Königlische Bohmischen Gesellschaft der Wissenschaften 5(10), 41-43.

ŠTĚPÁNEK, M., VESELÝ, J. \& MAJER, V. 1992. The major importance of nitrate increase for the acidification of two lakes in Bohemia. Documenta dell'Istituto Italiano di Idrobiologia 32, 83-92.

VESELÝ, J. 1994. Investigation of the nature of the Šumava lakes: a review. Časopis Národního muzea, ̌̌ada př́rodovědná 163(1-4), 103-120.

VESELÝ, J. 1996. Změny složení vod šumavských jezer v letech 1984 až 1995; Trends in acid-base status of acidified lakes in Bohemian Forest: 1984-1995. Silva Gabreta 1, 129-141.

VESELÝ, J. 2000a. The history of metal pollution recorded in the sediments of Bohemian Forest lakes: Since the Bronze Age to the Present. Silva Gabreta 4, 147-166.

VESELÝ, J. 2000b. Trace elements in Bohemian Forest lakes. Silva Gabreta 4, 167-178.

VESELÝ, J. \& MAJER, V. 1992. The major importance of nitrate increase for the acidification of two lakes in Bohemia. Documenti Instituto Italiano di Idrobiologia 32, 83-92.

VESELÝ, J., MAJER, V. \& KOPÁČEK, J. 2004. Vliv oteplování na chemismus vod šumavských jezer (Climate warming and chemistry of the Bohemian forest lakes), 95-97. In DVOŘÁ, L. \& ŠUSTR, P. (eds) Sborník z konference Aktuality šumavského výzkumu 2, Srní. Správa NP Šumava, Vimperk.

VRBA, J., FOTT, J., KoHOUT, J. \& KopÁČEK, L. 2004. Současné zotavování acidifikovaných jezer na Šumavě (Recent recovery of acidified lakes in the Bohemians forest), 99-103. In DVOŘÁK, L. \& ŠUSTR, P. (eds) Sborník z konference Aktuality šumavského výzkumu 2, Srní. Správa NP Šumava, Vimperk.

VRBA, J., FOTt, J., KopÁČEK, J., NedBAlOVÁ, L. \& NedOMA, J. 2001. Dlouhodobý limnologický výzkum šumavských jezer a jejich současný stav. Konference Aktuality šumavského výzkumu (Srní 2.-4.4. 2002), 56-57.

VRbA, J., KopÁČEK, J., BitTl, T., NedOMA, J., TrojSOVÁ, A., NedBalovÁ, L., Kohout, L. \& FotT, J. 2006. A key role of aluminium in phosphorus availability, food web structure, and plankton dynamics in strongly acidified lakes. Biologia 61(20), S441-S451. DO1 10.2478/s11756-007-0077-5

VRBA, J., KOPÁČEK, J. \& FOTT, J. 2000. Long-term limnological research of the Bohemian Forest lakes and their recent status. Silva Gabreta 4, 7-28.

VRBA, J., KOPÁČEK, J. \& FOTT, J. 2002. Šumavská ledovcová jezera na přelomu tisíciletí. Živa 6, 265-269.

VRBA, J., KopÁČEK, J., FOTT, J., KoHout, L., NedBAlOVÁ, L., PrAŽÁKOVÁ, M., SOldán, T. \& SCHAUMBURG, J. 2003. Long-term studies (1871-2000) on acidification and recovery of lakes in the Bohemian Forest (central Europe). The Science of the Total Environment 310, 73-85. DOI 10.1016/S0048-9697(02)00624-1

VRba, J., KopÁČeK, J., Straškrabová, V., Hejzlar, J. \& ŠIMEK, K. 1996. Limnological research of acidified lakes in Czech part of the Šumava Mountains: trophic status and dominance of microbial food webs. Silva Gabreta 1, 151-164. 